\title{
Ten paradigms of ancillary antonymy: Evidence from Classical Arabic ${ }^{(*)}$
}

\author{
Hamada S. A. Hassanein, PhD \\ Department of Foreign Languages (English), \\ College of Education, Mansoura University
}

\section{Abstract:}

Ancillary antonymy (strictly opposition), a top-listed category in the state-ofthe-art typology of antonymy in English, has been rigorously tested, retrieved and replicated over the past fifteen years across a variety of languages: Swedish, Japanese, Dutch, Serbian, Qur'anic Arabic, Chinese, Modern Standard Arabic, and Classical Arabic. However, three other counter studies have stripped this crosslinguistically preponderant category out of their taxonomies despite evidence that a great number of ancillary antonymy cases have been logged in their datasets. Using three Classical Arabic datasets, this study aims to provide strong evidence that champions this phenomenon and to propose ten paradigms of its usage therein. The study draws heavily upon the frame-based analytical methods developed in lexical semantics to serve its typological purpose. Results indicate that canonical, less canonical, and noncanonical pairs of opposition are interchangeably employed to signal, sharpen, and trigger each other on the syntagmatic axis. They also show that ancillary antonymy in Classical Arabic has nine more paradigmatic configurations, the most notable of which is the interchangeable opposition of duplicates, analogs, synonyms, and meronyms.

Keywords: al-ṭibāq/antonymy, al-muqābala/opposition, ancillary antonymy/opposition, paradigms, Classical Arabic

${ }^{(*)}$ Bulletin of the Faculty of Arts Volume 80 Issue 8 October 2020 


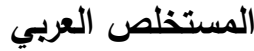

الطِبَاقَ المساعِد (المُقابَلَة بلغة أدق) من أهم الفئات المُدْرجة في التصنيف المُعاصِر لظاهرة الطِبَاق في اللغة الإنجليزية، وقد تم اختبار هذا التصنيف النَّوذجي باستخدامه وتطبيقه عملياً على مدار الخمس عشرة سنة الأخيرة في عدة لغات مختلفة منها السويدية

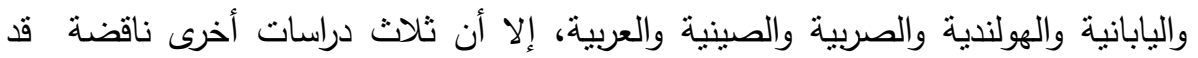

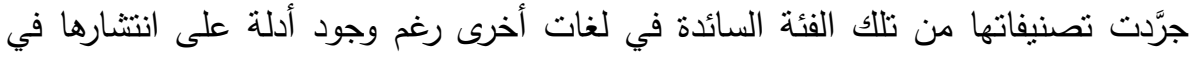
منونها. تهدف هذه الدراسة إلى تحليل ثنلاثة منون في العربية الفصحى لإقامة الدليل على ونى

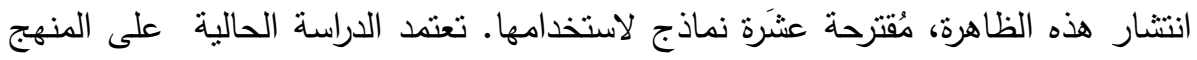

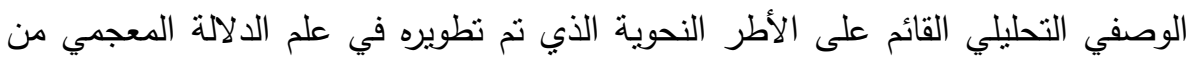

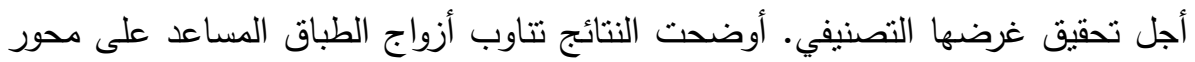
التضام في تركيب ذي ثلاث شُعَب مُصنطلح عليها وشبه مُصنطلَح عليها وغير مُصنطلح

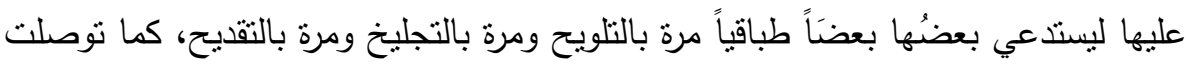

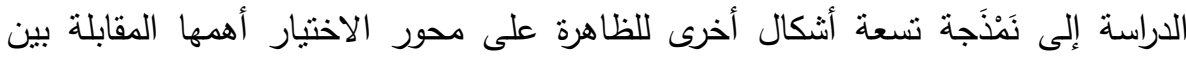

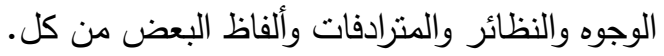

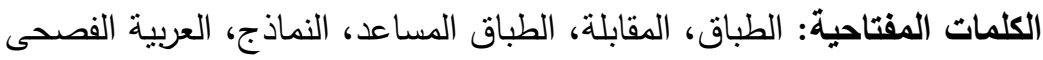

\section{Introduction}

Many lexical-semantic endeavors were made to model the phenomenon of antonymy and/or opposition in English and several heterogeneous typologies emerged from these scholarly endeavors (cf. Stamenov, 1992:14). The typologies seem to have been informed, I would claim, by two major pragmatic approaches: paradigmatic and syntagmatic, Jakobson's axes of selection and combination (cf. Simpson, 2004:35). The paradigmatic approach represents the lexicalsemantic choices from which one choice is made over the others (X or Ys), whereas the syntagmatic approach connects lexical-semantic 
elements along a meaningful structural frame (X and $\mathrm{Y}$ ). Traditional endeavors seem to have favored the former approach and built their typologies on a syntax-free relation between opposite or antonymous pairs, which might explain why such typologies are limited and static. Lyons (1968, 1977, 1995) and Cruse (1976, 1986, 2000) are the precursors of this approach, the purpose of which was exemplification based on promising but unrepresentative data, "not taken from actual instances of discourse" (Davies, 2012:43).

Modern endeavors, commencing with Justeson and Katz's (1991) corpus-based study into adjectival antonyms in English, have adopted the syntagmatic approach to study antonymy in a wider sense, the most suitable terminological alternative of which is opposition. ${ }^{(1)}$ Although Justeson and Katz (1991) were the first to have examined antonymous adjectives based on a co-occurrence hypothesis, i.e. those adjectives tend to co-occur in 'syntactically parallel and usually lexically identical structures' (Justeson and Katz, 1991:11) without a systematic classification (cf. Jones, 2002:21), Mettinger (1994) seems to be the originator of a typological syntagmatic analysis of the aspects of semantic opposition in English and adopts, as Jones (2002:22) describes it, a more structuralist perspective than Justeson and Katz (1991). Using a larger corpus, Jones (2002) conducted a more comprehensive study, presumably inspired by Mettinger (1994), and developed a more retrievable and more replicable typology of the discourse functions of canonical antonymy in text, attaching to each function a number of syntactic frames (e.g., 'exhaustive (disjunctive) coordination' as in 'either X or Y'). Jones's (2002) typology served as an analytical toolkit for subsequent syntagmatic studies into antonymy and/or opposition across other genres and languages (e.g., Jones, 2006, 2007; Murphy and Jones, 2008; Murphy et al., 2009; Muehleisen and Isono, 2009; Lobanova et al., 2010; Kostić, 2011; Hassanein, 2013a; Hsu, 2015, among others). 
In all the typologies created in previous studies, ancillary antonymy primes and dominates over all the other categories (cf. Jones, 2002, 2006; Jones and Murphy, 2003; Murphy and Jones, 2008; Murphy et al., 2009; Muehleisen and Isono, 2009; Lobanova et al., 2010; Kostić, 2011, 2016), which is the main justification why it receives due attention in the present inquiry, besides the following reasons. First, ancillary antonymy is a more contrastive discourse function than coordinated antonymy, used to introduce or emphasize another nearby contrast (cf. Murphy and Jones, 2008:422; Hsu, 2015:61; Kostić, 2016:6) between canonical, less canonical and noncanonical opposites. Next, ancillary antonymy accommodates a variety of syntactic frames from other categories and, therefore, is assigned no specific lexico-syntactic frames (cf. Jones, 2006:205; Lobanova et al., 2010:25; Davies, 2012:48; Hsu, 2015:58). Third, the ancillary function is, as Jones (2002:47) puts it, common not merely among opposites in text but also across language in general, serving usually to draw attention to a primary and more important (cf. Jones, 2002:5160), not secondary (cf. Muehleisen and Isono, 2009:2186), contrast.

Ancillary antonymy, a major top category in the syntagmatic typologies of antonymy, is too prevalent and dominant across genres and languages to drop out of use and be eliminated. Davies (2012), unlike all his predecessors who provided evidence from different language datasets for the dominance of this function, removed it from his qualitative typological analysis on no specific grounds. However, he (2012:45) gives all the credit to Jones's (2002) category of ancillary antonymy for being the trigger of noncanonical oppositions, a category in which two lexemes become opposites because they cooccur in the same syntactic frame in which two canonical opposites co-occur. Despite the credit it is given as a trigger of noncanonical oppositions and its dominance across different languages, such as English (Jones, 2002), Swedish (Murphy et al., 2009), Japanese (Muehleisen and Isono, 2009), Dutch (Lobanova et al., 2010), Serbian 
(Kostić, 2011), Arabic (Hassanein, 2013a, 2018) and Chinese (Hsu, 2015), ancillary antonymy receives no distribution in Davies's (2012) provisional typology and no examples of it were logged in his dataset. AlHedayani (2016) proved ancillary antonymy to be prevalent in MSA discourse. Nonetheless, she removed it from her classification on grounds that also apply to other transcategorial classes, such as idiomatic expression, and divided it into subclasses, instead.

\section{Literature review}

\subsection{Quantitative analyses of ancillary antonymy across genres and languages}

\subsubsection{Quantification of ancillary antonymy in English}

Jones's (2002) corpus-based study of antonymy is the cornerstone of syntagmatic analyses of antonymy across languages. In his seminal study, Jones proposed a new syntax-dependent typology of the discourse functions of antonymy in text. Ancillary antonymy dominates the frequency distribution, accounting for 1,162 sentences and $38.7 \%$ within a 3,000-sentence database taken from a 280million-word corpus of journalistic text. Jones and Murphy (2005) quantified ancillary antonymy in an ANR corpus of 415 (270 childproduced speech (CPS) and 145 child-directed speech (CDS)) instances of antonym co-occurrence, ranking it first and assigning to it $45.6 \%$ in CPS and 39.1\% in CDS. Drawing on a dataset of 955 antonymy co-occurrences extracted from a 10.37-million-word BNC spoken, Jones (2006) quantified ancillary antonymy, ranking it second to coordinated antonymy and assigning $28.8 \%$ to it. Jones (2007) confirmed the continuing dominance of ancillary antonymy by quantifying it across four domains or corpora (APW, APS, CPS and $\mathrm{CDS}$ ), the percentage distributions of which are $38.7 \%, 28.8 \%, 45.6 \%$ and $39.1 \%$, respectively. In Murphy and Jones (2008), ancillary antonymy comes first in rank in child speech, child-directed adult speech and newspaper corpus, accounting for $36.7 \%, 31.9 \%$, and 
$38.7 \%$, respectively, but second in rank in adult-directed adult speech, accounting for $28.8 \%$.

\subsubsection{Quantification of ancillary antonymy across other languages}

Murphy et al. (2009) took the initiative in quantifying ancillary antonymy across a language other than English, namely Swedish, based on a Swedish Parole corpus of 4366 cases of co-occurring antonyms, and allotted 44.8\% (1956 cases) for it. Muehleisen and Isono (2009) conducted a next cross-linguistic analysis of antonymy co-occurrence in 600 study corpus sentences, ranking ancillary antonymy as the most common function, accounting for $54.8 \%$ (329) of the database sentences. Using sets of adjectival seed antonym pairs, Lobanova et al. (2010) hypothesized that ancillary antonymy, one of the largest identified classes, would be the most frequent textual function in Dutch if cross-categorical pairs, i.e., pairs across word class (Fellbaum, 1995), were also added. Using an Untagged Electronic Corpus of Serbian, Kostić (2011) conducted a quantitative study of antonym co-occurrence in written Serbian and identified ancillary antonymy as the second largest category, accounting for a third (33\%) of the dataset. Hsu (2015) quantified antonym cooccurrences in the Chinese Gigaword Corpus and ranked ancillary antonymy as the second commonest category, occupying $21.7 \%$ of the data. AlHedayani (2016) quantified antonymy in MSA and found ancillary antonymy in 491 sentences, making $16.63 \%$ of her dataset. Hassanein (2018) quantified ancillary opposition in the Hadith discourse, ranking it first with a frequency distribution of $44.2 \%$ in his dataset.

\subsection{Qualitative analyses of ancillary antonymy across genres and languages}

\subsubsection{Qualification of ancillary antonymy in English}

Jones (2002:45-60) was the first to have identified ancillary antonymy and logged numerous instances thereof. In his view, this 
class includes two pairs: A-pair and B-pair. The A-pair becomes ancillary to the B-pair and instructs us to treat the B-pair more contrastively. If the B-pair has no innate element of opposition, the Apair generates an instantial contrast, as in 'I love to cook but I hate doing the dishes'. If the B-pair already has a low level of innate opposition, the A-pair activates this latent contrastive potential, as in 'The bad news is now largely behind, the good news is to come'. If the B-pair already has a high level of innate opposition, the A-pair affirms this contrast to the point of antonymity, as in 'extroverts are most motivated by reward while introverts respond more to punishment' (italics added). In this manner, the B-pair is nudged further up the scale of opposition by the A-pair. Since its inception in Jones (2002), ancillary antonymy has been confirmed by subsequent studies to perform an inexorable role in signaling canonical oppositions, sharpening less canonical oppositions and triggering noncanonical ones across languages and genres. This supports Jones's (2002:45) argument that the ancillary role is a relatively widespread phenomenon common not merely among 'opposites' in text, but also across language in general. Jones and Murphy (2005:407-410) found ancillary antonymy a complex category with particular usefulness in structuring discourse. Jones (2006:204-206) found ancillary antonymy more conceptually and grammatically complex than the other discourse functions; it features two oppositions and uses no specific syntactic framework. Jones (2007:1110-1111) arrived at very similar findings in previous works, confirming the everyday usefulness of the ancillary role in spoken interaction. Murphy and Jones (2008:422423) replicated similar results, revealing that ancillary antonymy presents a particularly clear antonymic input and reflects, what Lyons (1977:277) calls 'a general human tendency to categorize experience in terms of dichotomous contrast'. 


\subsubsection{Qualification of ancillary antonymy across other languages}

Murphy et al. (2009:2166-2167) reveal that ancillary antonymy in Swedish is not associated with any lexico-syntactic frame, is marked by morpho-syntactic parallelism and is manipulated in a recognizable manner similar to its counterpart in English. Muehleisen and Isono (2009:2192-2193) replicate similar findings that ancillary antonyms act as triggers for other contrasts motivated by syntactic parallelisms. Lobanova et al. (2010:25) refer to the superiority of ancillary antonymy over all other categories in Dutch, even with the omission of antonymous concepts expressed by words from different classes. Kostić $(2011,2015,2017)$ foregrounds ancillary antonymy in Serbian and provides three strong cases in favor of Jones's (2002) argument for this category: an A-pair of well-established antonyms serve to draw our attention to a more important contrast between pairs that are conventional antonyms (i.e., canonical), pairs that are probably opposable in certain contexts (i.e., less canonical) and pairs that are difficult to oppose in context (i.e., noncanonical). Thus, she establishes that the contrast between the A-pair antonyms is so entrenched in our mental lexicon that we can still label this function 'ancillary', or what she more strictly calls 'reciprocally ancillatory', antonymy. Hsu (2015:61-62) typifies ancillary antonymy in a Chinese corpus, with two mappings ( $A$ mapped to $X$ and $B$ mapped to $Y$ ) and five permutation patterns (XAYB, AXBY, AXYB, ABXY and $\mathrm{XYAB})$.

Hassanein (2013a:143-151) identifies and exemplifies two guises of ancillary antonymy in Qur'anic Arabic (QA) at an intrasentential or intraversial $^{(2)}$ level: canonical A-pair antonyms that generate another central contrast between (non)canonical intratextualized or metatextualized B-pairs. The intratextual pairs of antonyms co-occur in text and hence are easily retrievable, while the metatextual ones are textually absent but conceptually comprehensible. AlHedayani (2016:3) literally writes, “Triggering opposition between canonically 
unopposed phrases in this (i.e., 'ancillary') way has been found in all genres and languages investigated so far, including the present study." Despite the statistically significant role of ancillary antonymy, she prefers to remove it from her typology for two main reasons:

a) the ancillary use of antonyms is an effect projected on other words regardless of the hosting syntactic construction and

b) there are no objective criteria for including a sentence under ancillary antonymy.

Hassanein (2018:14-16) presented a broader perspective on ancillary opposition in the major collections of Hadīth (Șahīh al-Buhārī (SB) and Șạīh Muslim (SM)), profiling three facets of how ancillary opposition is specifically used in Hadīth Arabic:

a) less canonical pairs of opposites signaling opposition between canonical pairs,

b) canonical pairs of opposites signaling opposition between noncanonical pairs, and

c) noncanonical text-based pairs instantiating oppositions between canonical context-based pairs of opposites.

Hassanein's (2013a, 2018) research on opposition in CA (the Qur'an and Hadīth) prosecutes arguments and cases that confirm the ancillary role which antonymy plays in creating or consolidating oppositions between (non)canonical pairs in Arabic discourse.

\section{This study}

The universal pervasion of antonymy underlines the human cognitive tendency toward binary contrast, which Murphy (2003:43) calls Relation by Contrast (RC) as a general cognitive relation, not just a means for relating word concepts. The RC holds that items are related if they are minimally different in contextually appropriate ways. The principle sets no limit to the constitution of contrastive pairs, which might be supported by Jones's (2002) low innate and no innate oppositions between the B-pair members of ancillary antonymy 
and Davies's (2012) noncanonical oppositions. Kostić (2016) confirms the RC stipulation that the contrast relation is derivable between any form-meaning pairing construed as opposites in discourse between canonical, less canonical and noncanonical pairings. The advantage of the $\mathrm{RC}$ approach is that opposition is triggered between members of a noncanonical pair, which belong to the same syntactic frame and discourse function as the (less)canonical ones.

This study builds on the RC approach and follows a multifaceted approach to the analysis of ancillary antonymy in the major Classical Arabic texts. The approach shifts focus from one discipline to an interplay between different disciplines-i.e., cognitive, corpus and exegetical approaches - and from one level to several interrelated levels-i.e., lexical, semantic, and conceptual. There is a current debate concerning the degree to which ancillary antonymy or opposition is cross-culturally or cross-linguistically particularistic or universalistic. In this study, I am prone to give evidence for universal commonalities between English and Arabic ancillary antonymies and for the particularities of ancillary antonymy, al-tibāq, in CA per se.

The significance of this study consists in building a theoretical profile and an empirical framework, which account for how Jones's (2002) category of ancillary antonymy acts as a pervasive mode of thought in language use and in the process of meaning construction and consumption across other languages and cultures, with Classical Arabic as one case in point. Despite the fact that the profile of this category in English (cf. Jones, 2002; Jones, 2007) has some guises in common with its profile in Classical Arabic, ancillary opposition also functions distinctly in Classical Arabic and casts opposition not only on canonically opposite pairs but also on nonopposites. Opposition is not merely a lexical association phenomenon but also a knowledgeconstructing process (Murphy and Andrews, 1993; Murphy, 2003; Paradis et al., 2009). Ancillary opposition in particular is shown to be lexical, semantic and conceptual in nature (Murphy 2003; Jones et al. 


\section{Analysis}

\subsection{Ancillary Constructions: A Cross-categorial Quantitative Analysis}

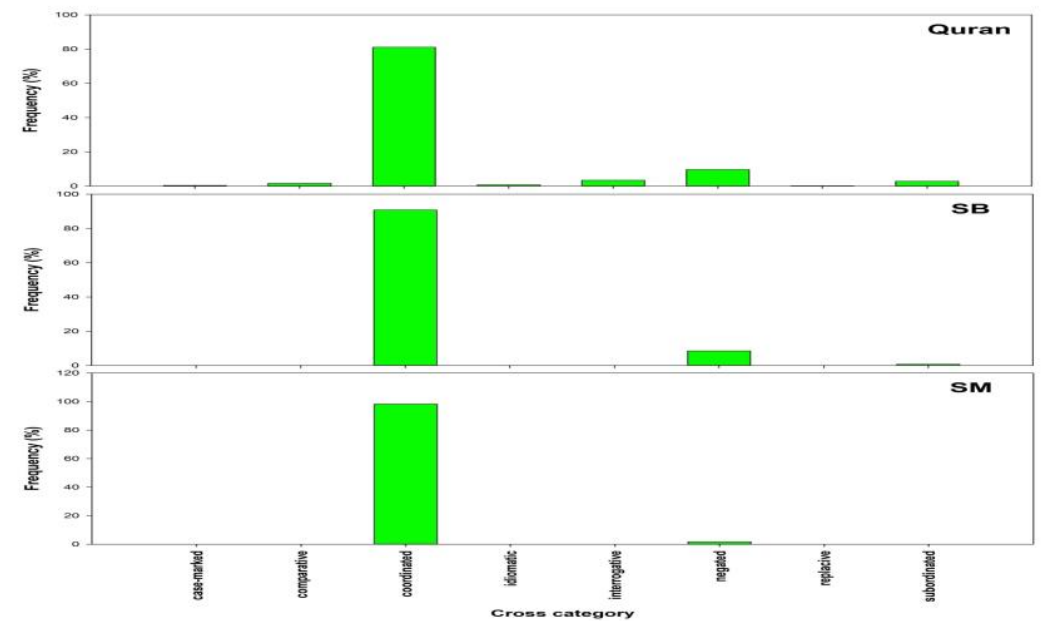

Figure 1 Frequencies of ancillary oppositions across categories in Q,

SB and SM

Figure 1 shows that coordinated opposition is the favorite category for ancillary opposition, with the highest frequency distribution (more than 80\%) across the three datasets: the Qur'an, SB and SM. Negated and interrogative oppositions rank second and third, respectively, with much less frequencies compared with coordinated opposition, however. Subordinated opposition, first developed by Hassanein (2013a) and further supported by AlHedayani (2016) and Hassanein (2018), comes fourth in order in the Q and SB from which ancillary opposition also borrows syntactic frameworks. Interrogative opposition holds the fifth place and lends ancillary opposition some of its typical frameworks. It is also shown that ancillary opposition accommodates cross-categorial syntactic frameworks from a larger number of categories in the Q than in SB and SM: eight, three and two categories, respectively. 

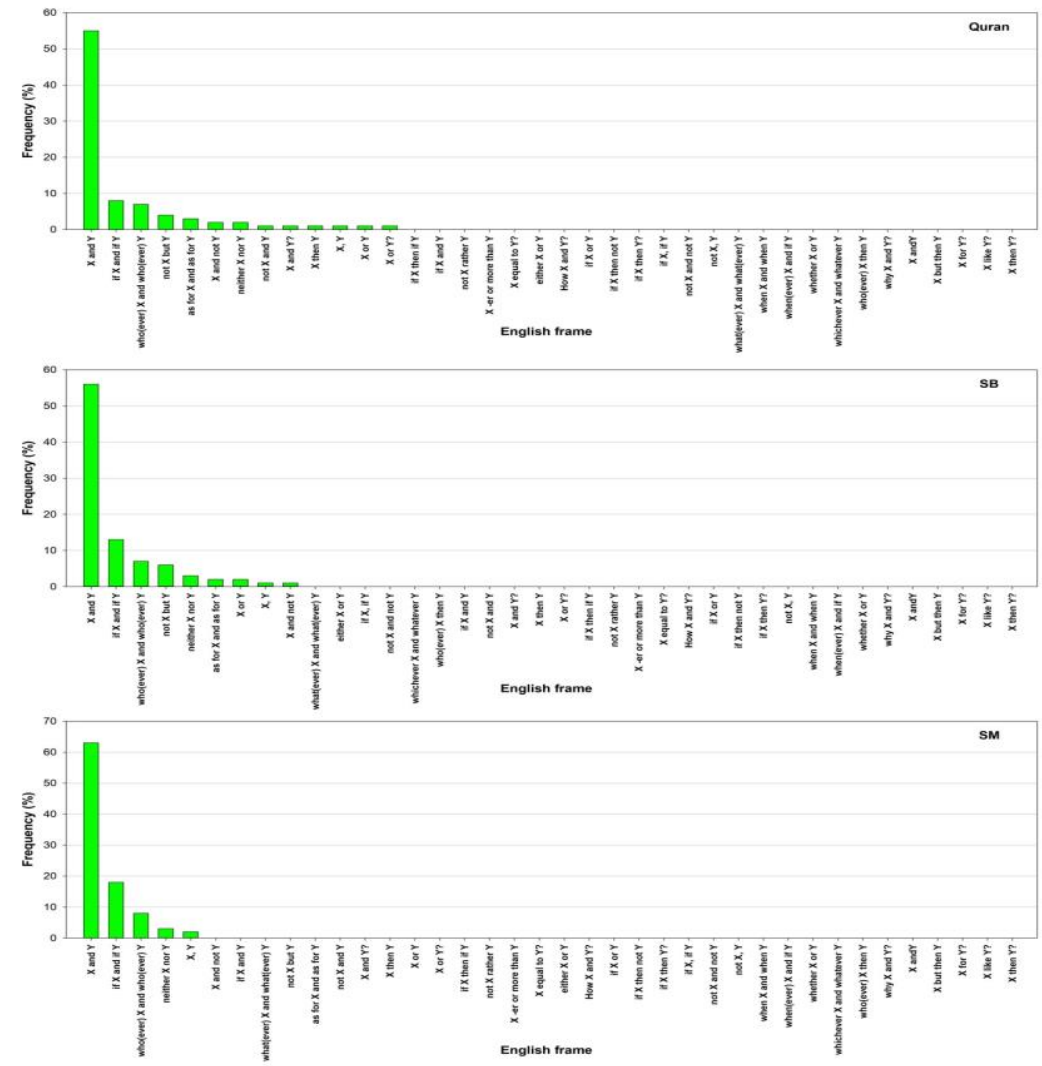

Figure 2 Frequencies of ancillary syntactic frames across categories in $\mathrm{Q}, \mathrm{SB}$ and SM

Figure 2 shows that ancillary opposition employs a greater number of syntactic frameworks in the Q than in SB and SM. There is a quite logical correspondence between the most dominant categories favored by ancillary opposition and their respective frameworks. It is shown that the syntactic frames specific to coordinated opposition are mostly manipulated by ancillary opposition. A large number of coordinated frames are in use, but the frames $X$ AND Y, IF X AND IF Y and WHO(EVER) X AND WHO(EVER) Y are top-listed. The first frame is statistically beyond comparison with the other two, taking up more 
than 55\% across the entire datasets. Negated opposition contributes some typical frames NOT X BUT Y, X AND NOT Y and NOT X AND Y.

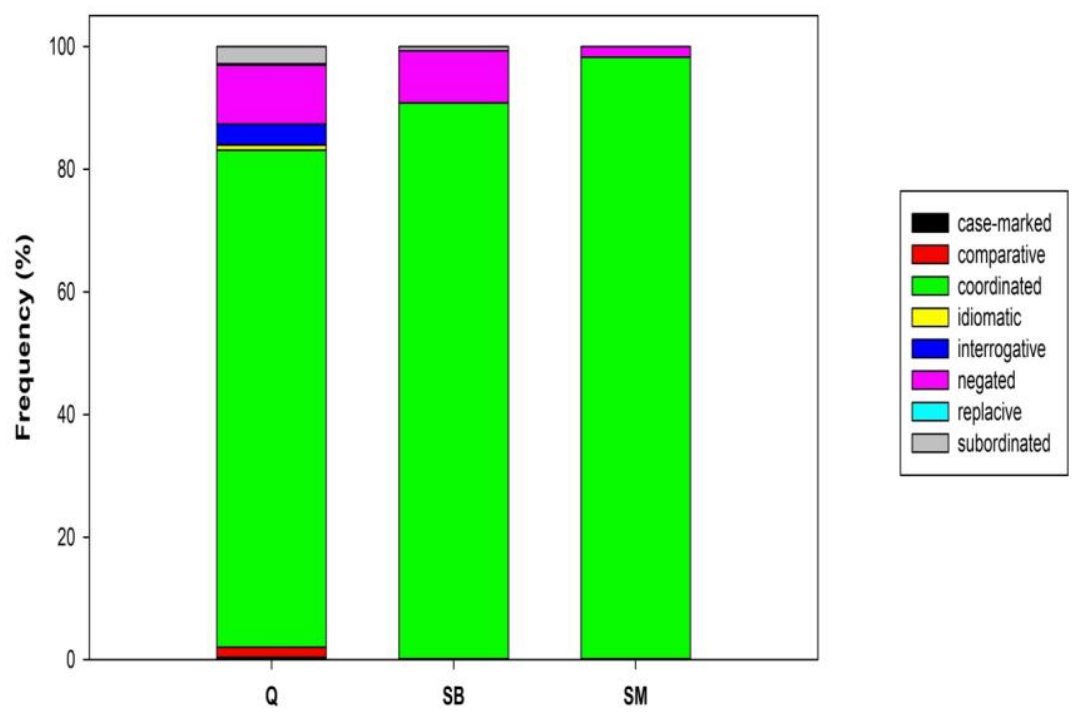

Figure 3 Frequencies of the categories in Q, SB and SM

Figure 3 shows the superiority of the Q over SB and SM in the number of discourse-functional categories accommodated by ancillary antonymy or opposition in the three related corpora: eight, three and two, respectively. Two categories, the coordinated and negated oppositions, are dominant in the three datasets. A newly developed class, subordinated antonymy (Hassanein, 2013a) or opposition (Hassanein, 2018) is shared by the $\mathrm{Q}$ and SB, with much higher frequency in the former than in the latter. Coordinated opposition stands out as the greatest provider for ancillary opposition and lends it a far larger number of frames. Clearly, the preponderance of coordinated functions and frames features across all datasets in general but in SM in particular. Ancillary opposition favors coordinated opposition and takes it as a more intimate bedfellow. 
Table 1 Ancillary-induced coordinated, negated and subordinated oppositions in SB

\begin{tabular}{lllll}
\hline PART & coordinated & negated & subordinated & Total \\
\hline 1 & 30 & 4 & 0 & 34 \\
2 & 40 & 4 & 0 & 44 \\
3 & 10 & 0 & 0 & 10 \\
4 & 36 & 2 & 0 & 38 \\
5 & 0 & 4 & 0 & 4 \\
6 & 48 & 0 & 2 & 50 \\
7 & 57 & 8 & 0 & 65 \\
8 & 36 & 2 & 0 & 38 \\
Total & 257 & 24 & 2 & 283 \\
\hline
\end{tabular}

Table 2 Ancillary-induced coordinated, negated and subordinated frames in SB

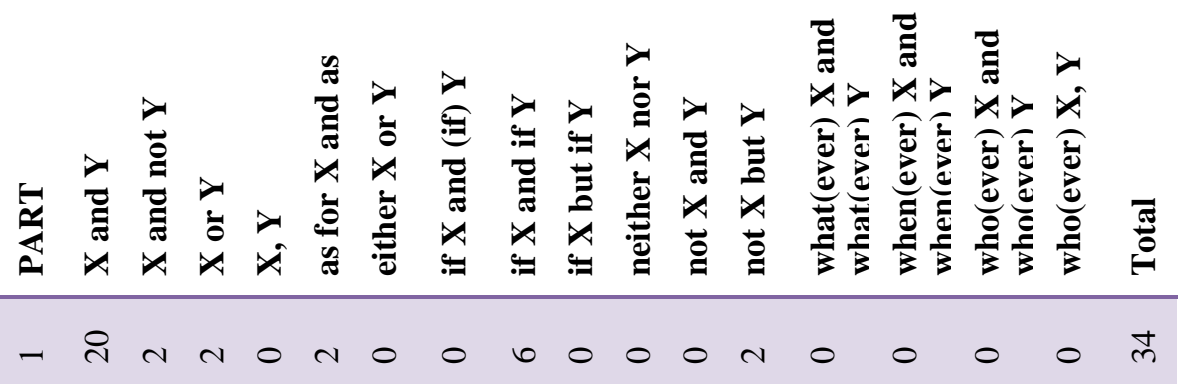

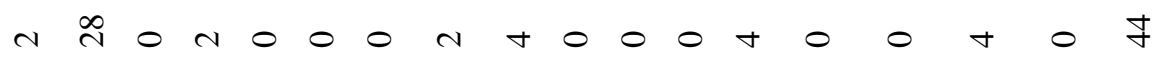

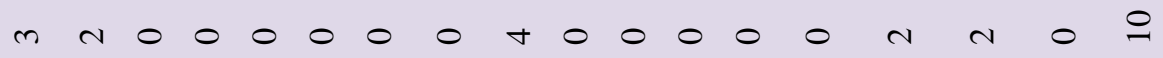

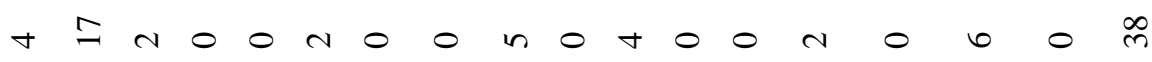

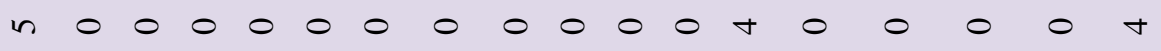

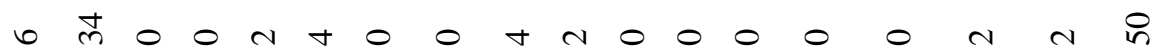

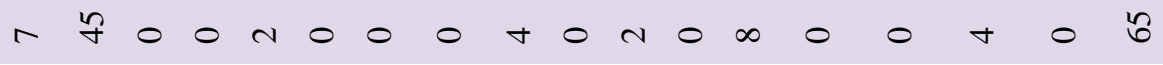

$$
\begin{aligned}
& \infty \operatorname{mon} 00 n \text { h }
\end{aligned}
$$

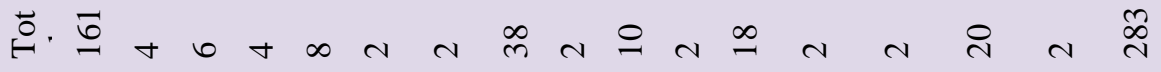


Tables 1 and 2 show the frequencies of three common categories, coordinated (257 $n(90.8 \%))$, negated opposition (24 $n(8.4 \%))$ and subordinated opposition $(2 n,(0.7 \%))$, and their respectively favored frameworks, X AND Y $(161 n(56.8 \%))$, NOT X BUT Y $(18 n$ $(6.3 \%))$ and WHOEVER X, Y (2 $n(0.7 \%))$, employed in an ancillary fashion.

Table 3 Ancillary-induced coordinated and negated oppositions in SM

\begin{tabular}{llll}
\hline PART & coordinated & negated & Total \\
\hline 1 & 20 & 0 & 20 \\
2 & 26 & 0 & 26 \\
3 & 27 & 0 & 27 \\
4 & 10 & 0 & 10 \\
5 & 17 & 0 & 17 \\
6 & 13 & 2 & 15 \\
7 & 12 & 0 & 12 \\
8 & 101 & 2 & 103 \\
Total & 226 & 4 & 230 \\
\hline
\end{tabular}


Table 4 Ancillary-induced coordinated and negated frames in SM

\begin{tabular}{|c|c|c|c|c|c|c|c|c|c|c|c|c|}
\hline$\underset{\frac{1}{\alpha}}{\stackrel{2}{2}}$ & $\begin{array}{l}\searrow \\
\bar{\Xi} \\
\dot{\Xi} \\
x\end{array}$ & 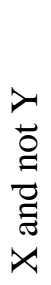 & $\begin{array}{l}\underset{ }{\not} \\
\stackrel{0}{O} \\
\ddot{x}\end{array}$ & $\vec{x}$ & $\begin{array}{l}\nu \\
\vec{\partial} \\
\tilde{E} \\
\dot{x} \\
.\end{array}$ & 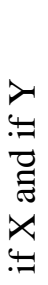 & 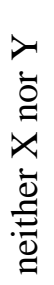 & 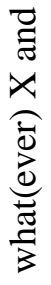 & 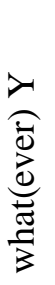 & 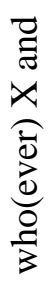 & 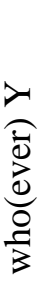 & $\stackrel{\pi}{0}$ \\
\hline- & $\stackrel{ }{ }$ & 0 & 0 & 0 & 0 & 6 & 0 & 0 & & $\nabla$ & & గి \\
\hline$N$ & 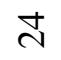 & 0 & 0 & 0 & 0 & N & 0 & 0 & & 0 & & లి \\
\hline$m$ & $\bar{N}$ & 0 & 0 & 0 & $N$ & N & 0 & 0 & & N & & $\widehat{N}$ \\
\hline$\nabla$ & 6 & 0 & 0 & 0 & 0 & N & $N$ & 0 & & 0 & & $\stackrel{0}{0}$ \\
\hline$n$ & 6 & 0 & 0 & 0 & 0 & $a$ & 0 & 0 & & N & & I \\
\hline 6 & $r$ & N & 0 & 0 & 0 & 0 & 0 & 0 & & 6 & & $n$ \\
\hline 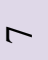 & $\stackrel{\varrho}{ }$ & 0 & 0 & 0 & 0 & $N$ & 0 & 0 & & 0 & & $\simeq$ \\
\hline$\infty$ & $\widehat{6}$ & 0 & N & $n$ & 0 & 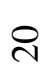 & 6 & N & & $n$ & & ڤㅇ \\
\hline & す & $N$ & N & $n$ & $N$ & $\stackrel{m}{\forall}$ & $\infty$ & N & & ㅇ & & 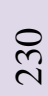 \\
\hline
\end{tabular}

Tables 3 and 4 provide frequency distributions of only two textual functions, the coordinated and negated categories (226 and $4 n$ (98.2 and $1.7 \%$ ), respectively), whose preferred frameworks are X AND Y $(147 n(63.9 \%))$ and X AND NOT Y and X NOT Y ( $n$ (0.8\% each)), respectively. A common link among the three datasets shows coordinated opposition as a pandemic category whose most favorite frame is X AND Y and negated opposition as a class more endemic to $\mathrm{Q}$ and SB than to SM. 


\subsection{Ancillary Constructions: A Cross-categorial Qualitative Analysis}

In this section, ancillary oppositions that accommodate syntactic frameworks from across other major and minor discourse functions are identified, exemplified and discussed: the A-pair members appear in italics; the B-pair ones in bold italics and the frames in capitals. ${ }^{(3)}$ The discourse functions are arranged in a descending order of their frequency distributions across ten provisional paradigms in the corpus. The sample examples are shortened to a phrasal or clausal form if their full sentential content is not necessary. Examples 1-3 feature a high innate opposition between the B-pair members, which are antonyms in themselves nudged up the scale by the A-pair antonyms (cf. Jones, 2002:47).

\subsubsection{Canonical opposites as ancillary signalers of canonical ones in a coordinated frame}

The ancillary oppositions below exemplify PARADIGM I and feature pairs of canonical, i.e., conventional, opposites (A-pairs) used as ancillaries to emphasize the inherent opposition between other pairs of canonical opposites (B-pairs) and conjoined by coordinating and correlative conjunctions. Coordinators are mnemonically packed in the acronym 'fanboys' while correlators come in pairs, with both-and and neither-nor figuring as the major ones. In the present study, coordinators and correlators are both classed under coordination, following Jones's (2007:1111) premise that the strings conjoined by and and or are often preceded by both, (n)either, or whether. Coordination signals an equal status of inclusiveness and/or exclusiveness, as well as junction or disjunction, within affirmative or negative contrastive constructions. 

Bulletin of the Faculty of Arts Volume 80 Issue 8 October 2020

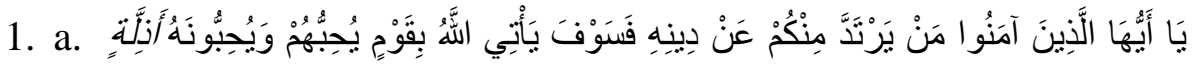

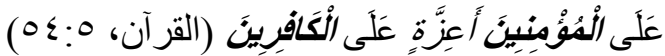

b. You who believe, if any of you go back on your faith, God will soon replace you with people He loves and who love Him, people who are gentle with the believers, harsh with the unbelievers. (Q, 5:54)

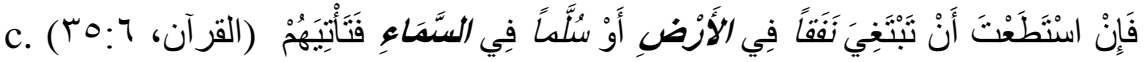
بَآيَةٍ

d. If you would be able to seek a tunnel into the ground OR a ladder into the sky, bring them a sign. (Q, 6:35)

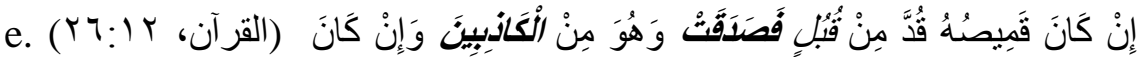

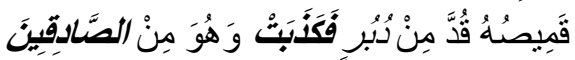

f. If his shirt is torn at the front, then it is she who is telling the truth and he who is lying, but if it is torn at the back, then she is lying and he is telling the truth. (Q, 12:26)

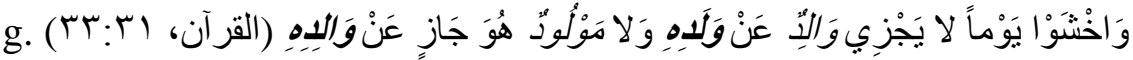

h. And fear a day when NEITHER parent will take the place of their child NOR a child will take the place of their parent. (Q, $31: 33)$

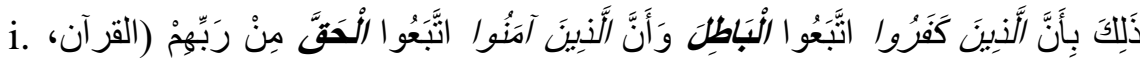
$(\Gamma: \leqslant \vee$

j. This is because who disbelieve follow falsehood AND who believe follow the truth from their Lord. (Q, 47:3)

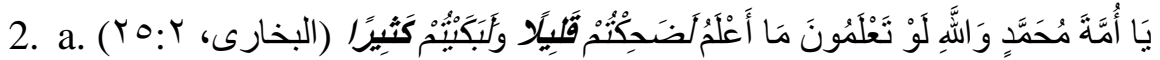

b. O Muhammad's community, I swear by God that if you had known what I have known, you would have laughed a little AND cried much. (SB, 2:25)

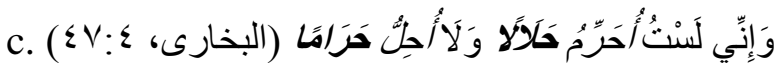

d. Certainly, I NEITHER proscribe a halal NOR prescribe a haram. (SB, 4:47) 


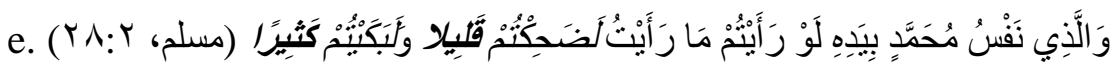

f. I swear by the One in whose hands Muhammad's soul resides that if you had seen what I have seen you would have laughed a little AND cried much. (SM, 2:28)

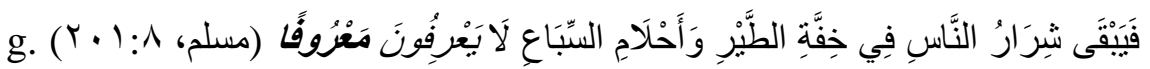
وَلَالِنْكِرُونَ مُنْكَرًا

h. The most evil of people would remain, as nimble as birds and as temperamental as wild animals, NEITHER approving (anything) good NOR condemning (anything) bad. (SM, 8:201)

Cases $1 \mathrm{a}-\mathrm{h}$ and $2 \mathrm{a}-\mathrm{h}$ constitute PARADIGM 1 in which pairs of canonical opposites (A-pairs) play an ancillary role in signaling an innate opposition between the subsequent pairs of canonical ones (Bpairs) and augmenting their contrastive power. In this paradigm, both A- and B-pairs feature proper antonyms in their own right and a mutual built-in contrariety, utilizing syntactic frameworks typical of coordinated opposition. Case 1a asyndetically conjoins two pairs of canonical opposites, referred to by Jones (2002:99) as 'simultaneous antonyms', within a bipartite paratactic structure, whose two parallel parts are connected together without any punctuation mark, Jones's (2002:96) 'oblique stroke', or coordinator, 'adilla/a'izza 'gentle/harsh' (A-pair) and al-kafirin/al-mu'minin 'unbelievers/ believers' (B-pair). Cases as such use parataxis as a tool to join predicative adjectives as post-modifiers of a preceding head noun, the purpose of which is to reveal the simultaneity of oppositional attitudes towards two different groups of people. Such cases are easily classed together due to their structural affinity, being used within uncoordinated and unpunctuated two-part parallel construction. God promises to replace whoever apostatizes from Islam with other people who will love Him, who will be gentle with the believers (and) harsh with the unbelievers and who will fear no reproach when calling a spade a spade (cf. al-Zamahsharī, 1998 [P2]:257). The implication is 
that the Islamic religion will always have staunch proponents and supporters no matter who would renegade from it (Ibn 'Āshūr, 1984 [P6]:234).

Using a disjunctive X OR Y frame, Case 1c coordinates the A-pair members nafaqā/sullamā 'tunnel/ladder' as the principal vectorial tools of reaching al- 'ard//al-samā' 'underground/sky' (B-pair). God is addressing and orienting his messenger Muhammad to two unrealizable alternatives that designate two opposite directions (technically reversives) ${ }^{(4)}$ in space. The implication is that the prophet Muhammad is realistically incapable of digging a tunnel into the wonders of the ground or putting up a ladder into the wonders of the sky to bring his people signs that drive them to believe in his God. This might explain why the conditional particle 'in 'if' is employed in this context. According to Ibn 'Āshūr (1984 [P7]:203-204), this conditional particle appears in contexts in which what is conditioned is just hypothetical and unlikely to happen. Al-Zamahsharī (1998 [P2]: 341) confirms this implication, adding that the prophet Muhammad is shown to have been so zealous in doing his utmost to show his reluctant people any possible sign they seek so that they have faith in his Lord.

Case 1e features a triad of oppositional pairs within coordinative conditional phrases 'IF X AND IF Y, THEN X AND THEN Y': qubul/dubur 'front/back', șadaqat/kadabat 'tell the truth/tell a lie' and al-kādibīn/al-șādiqīn 'the liars/the truth tellers'. In the prophet Joseph story, there occurred a sexual episode in which a foster mother seduced her foster son behind the back of her husband. Caught in the scene by the husband, the two of them started to exchange charges. A next of kin from the family used the foster son's torn shirt as tainted evidence to prove either of them (un)truthful. Hassanein (2013a:65) provides an interesting analysis of this complex-compound proposition: the contrary pair front/back supports Greimas's idea of binary oppositions on his semiotic square and also implies the 
negative of each term in the binary, the contradictory pair, which is not-front/not-back in this example. But the contradiction comprises much more than this: not-front/not-back include more than front/back. On the contradiction axis, alternative directional opposites, such as right/left, often posit themselves in the propositional analysis. Once these terms are laid out on the square, a relation of implication logically exists between terms on the vertical axes: front/not-back and back/not-front. Greimas (1983) defines the analysis of meaning at this level as deep semantics. The meaning of the single term is often defined by the neighboring terms in the cluster of themes in which it is placed. In this specific pair, opposition appears both syntagmatically between antonymous nouns and cliticized verbs and paradigmatically between the cliticized verbs and clauses.

Case $1 \mathrm{~g}$ conjoins a relational pair of opposites, wālid/mawlüd 'parent/child' (A-pair), in a conversive NEITHER X NOR Y framework in which what does not apply to X does not apply to Y, either. God is telling people in general to fear Him and to beware a Day, i.e., the Day of Judgement, on which a parent will not help his or her child and a child will not help his or her parent, with the converses $^{(5)}$ waladih/wālidih 'child/parent' serving as the B-pair members. A semantic nuance inherent to the Arabic A-pair resides in the distinction between the items mawlüd and walad, whereby the former refers to immediate parent-child relation and the latter refers to non-immediate relation (cf. Al-Zamahsharī, 1998 [P5]:25), possibly between (grand)parent(s) and (grand)child(ren). This semantic distinction is brought home to us through the case-marking borne by the second A-pair member mawlüd (patient or experiencer) in contraposition to wālid (agent). Ibn 'Āshūr (1984 [P21]:193) argues that the verse starts with wālid and then with mawlüd because parents are more sympathetic towards and concerned about their children in times of adversities. 
Case 1i contrasts relative clauses al-ladìna kafarū/al-ladīina āmanū 'who disbelieve/who believe' (A-pair) ${ }^{(6)}$ within an X AND Y frame to account for why the former's deeds would be nullified and the latter's bad deeds would be tolerated by God: because the former followed albätil; the latter followed al-haq from their Lord, 'falsehood/truth' (Bpair), respectively. The coordinator AND serves to conjoin two mutually exclusive opposites without a mid-term in between, whereby whoever is not faithful is necessarily faithless and what is not true is necessarily false, or vice versa. Ibn 'Āshūr (1984 [P26]:73) finds commencing the verse with a relative pronoun and a relative clause a suitable opening for a consequent judgment, hence creating great suspense on the part of readers. God structures information in a very unusual effect-and-cause, not cause-and-effect, style that foregrounds result and backgrounds reason. Causality is brought home to the readers by means of the causative particle $b i$ 'as, for, since, or because'. Ibn 'Āshūr (1984 [P26]:76) cites al-Kashshāf as labeling this unique style al-tafsir 'causation', which rhetoricians regard as an embellishing trope. The ideological implication is that the B-pair members, al-bätil/al-haq 'falsehood/truth', are shown to be the causes of the preceding injunctions for the A-pair ones: misguidance for those who disbelieve and forgiveness for those who believe.

Cases 2a-h show how ancillary opposition has been manipulated by the prophet of Islam in the two collections: SB and SM. Case 2a conjoins the A-pair members dahiktum/bakaytum 'laugh/cry' and the B-pair ones qalīlā/kathīrā 'little/much' within a conjunctive X AND $\mathrm{Y}$ frame. This frame hosts a templatic pattern of opposition remodeled by the prophet Muhammad from a formerly revealed Qur'anic verse (9:82), according to which evildoers are said to laugh a little in the worldly life but cry much in the afterlife. The prophet shows himself to be an encyclopedic messenger who has got broad knowledge of many things unknown to his people, the motivation of which is simply to intimidate his people (cf. Al-'Asqalān̄i, n.d. [P2]:529). The 
prophet's tradition has the implication that he might have seen some people laughing a lot and crying a little and for this reason he wanted to alarm them to take care not to be immersed in this life and pay more attention to the afterlife. Case 2e echoes the same templatic pattern (frame and pairs) but in a different context: the prophet moves his people from the knowledge plane to the vision or sight plane. The prophet seeks to instill an intimidation in his people and make an opposite change in their demeanor by warning them against things he has seen but they have not: Had they seen what he has seen, they would have laughed a little and then cried much.

Cases $2 \mathrm{c}$ and $2 \mathrm{~g}$ feature ancillary oppositions in a coordinative, more strictly correlative, framework NEITHER X NOR Y. Their syntactic environments display conjunctively negative structures in which both $\mathrm{X}$ - and Y-members are coupled together in order to signal inclusivity, neutrality and passivity on part of the speaker(s) or the people spoken about. Case $2 \mathrm{a}$ hosts the canonical A-pair 'uharrim/'uhill 'proscribe/prescribe' and the canonical B-pair halālā/harāmā 'halal/haram' to signal both inclusivity and neutrality on part of the prophet Muhammad. Abū 'Abd al-Raḥmān al-Miswar b. Mahrama heard the prophet delivering a complimentary speech about his son-in-law 'Alī b. 'Abī Țālib who proposed to marry the daughter of 'Ab̄i Jahl as a second wife besides his first wife Fātima, the prophet's daughter. After praising his son-in-law in front of the Muslims, the prophet justifies his flat refusal of this marriage proposal. The prophet takes a neutral stance from the halal-haram issue, not proscribing what is licit or prescribing what is illicit. His statement entails his dogged adherence to what is proscribed and what is prescribed. The prophet flatly refuses 'Alī b. 'Abī Țālib's marriage proposal to 'Abī Jahl's daughter, not because it is deemed unlawful by the prophet, since polygamy and polygyny are lawful in Islam, but because he deems it unwise and inappropriate to be simultaneously married to the daughter of the prophet of Islam and that of the enemy 
of Islam. For this reason, the prophet was entirely against this proposal, in addition to his foreboding that his daughter's faith might be negatively affected.

Case $2 \mathrm{~g}$ replicates the same syntactic framework of case $2 \mathrm{c}$, hosting the canonical A-pair and B-pair members ya 'rifün/yunkirūn 'approve/condemn' and ma 'rūfā/munkarāa 'good/bad', respectively, which convey both inclusivity and passivity on part of the remnant group of the people spoken about. The prophet prophesies one of the big heralds of apocalypse, a cold wind that will render each good person dead and leave the evil ones who will be as nimble as birds and as temperamental as wild animals and who will neither command good nor forbid evil. Then Satan will incarnate himself as a human, inviting those evil ones to idolatry. They will listen to him and remain like this until they all die. Although the syntactic environments of the A- and B-pairs are the same in cases $2 \mathrm{c}$ and $2 \mathrm{~g}$, each serves a different purpose and a different field: legislation (lawful/unlawful) and valuation (good/bad), respectively. Case 2c implies a commitment by the prophet of Islam in following what is licit and avoiding what is illicit, whereas case $2 \mathrm{~g}$ discloses non-commitment and indifference from the side of the evil remnants who will survive the deadly cold wind to be misguided and misled by the devil.

\subsubsection{Canonical opposites as ancillary signalers of canonical ones in a negated frame}

The cases below also belong to PARADIGM 1 and feature ancillary oppositions (canonical A- and B-pairs) in a negated frame, in which the A-pair members are negated in favor of the B-pair ones. The Apair opposites are negated to affirm and magnify their B-pair counterparts, employing mainly the archetypal framework NOT $\mathrm{X}$ BUT Y or variants thereof. Unlike English that uses the negative marker not as its main and perhaps only negative marker, except for the malleable $X$ instead of $Y$ and $X$ as opposed to $Y$ considered by Davies (2012) at home in the classes of replacive and explicit 
oppositions respectively, Classical Arabic enjoys a variety of negative markers, such as $m \bar{a}$, laysa, and $l \bar{a}$ amounting to not. A sharper and more important contrast is generated and confirmed in the B-pairs. Contrary to the case in English in which the X-position opposite is the 'surprise antonym' (cf. Jones, 2002:89), the so-called 'surprise antonymy' is often the Y-position opposite in Classical Arabic.

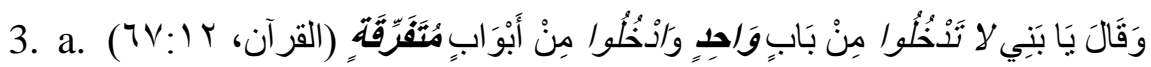

b. He said, 'My sons, do NOT enter all by one gate AND enter by different gates.' (Q, 12:67)

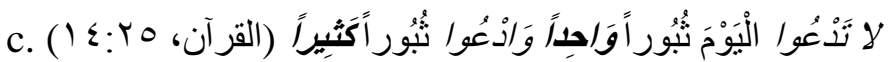

d. Do NOT cry out this day for one death, AND cry out for many deaths. (Q, 25:14)

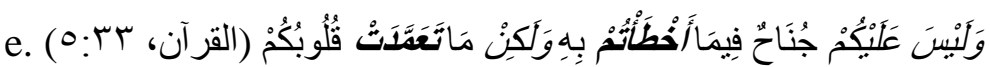

f. You will NOT be blamed for what you did by mistake, BUT (will be blamed) for what your hearts did on purpose. (Q, 33:5)

Cases 3a-e feature negated oppositions in which the X-members are de-emphasized in favor of Y-ones and thus they serve as ancillaries. Case $3 \mathrm{a}$ takes us back to the intriguing Joseph story in which the prophet Jacob advises his eleven sons to enter Memphis through different gates, not through the same gate, to remain safe from evil eyes, because they were arresting figures in any crowd (alZamahsharī, 1998 [P3]:306), or from evildoings (Ibn 'Āshūr, 1984 [P13]:20). The A-pair lā tadhulū/'idhulū 'not enter/enter' is negated in a NOT X AND Y framework to affirm the B-pair $b \bar{a} b$ wāhid/'abwāb mutafarriqa 'one gate/different gates'. The Arabic item wāhid is a polysemous word with two meanings, the same or one, each of which serves a distinct semantic plane, that of variety (several) and that of number (many). Ibn 'Āshūr (1984 [P13]:21) draws a polemical distinction between the Arabic terms al-mutafarriqa 'different/separate' and al-muta 'addida 'many/several'. To him, 
preference is given to the former over the latter on the grounds that they form a single group that should take separate entrances, not the same one, to guard against any harm. Individual entry is preferred to collective entry for safety reasons. Native speakers of Vernacular Arabic (VA) can intuitively draw a clear difference between wähid as same and wāhhid as one in distinct expressions, such as al-ṣurtain wähid 'The two pictures are the same' (not different) and al-rabb wăhid 'God is one' (not many). This argument is supported by case 3c.

Case $3 \mathrm{c}$ replicates the same syntactic framework NOT X AND Y and the same $\mathrm{X}$-member as in case $3 \mathrm{a}$, but includes a different $\mathrm{Y}$ member kathīrā 'many' in place of mutafarriqa 'different', hence shifting the semantic dimension from attribution or modification (mutafarriqa as a modifier) to quantification or specification (kathīrā as a specifier or quantifier). The A-pair $l \bar{a} \operatorname{tad}{ }^{\prime} \bar{u} / i d{ }^{\prime} \bar{u}$ 'not cry out/cry out' is negated in favor of the B-pair thubūran wāhidalthubūran kathīrā 'one death/many deaths'. In Arabic, as Hassanein (2017:145) puts it, the coordinator $w a$ 'and' is contextually potential when its conjoins are contrastive (cf. al-Ṣi 'î̀ī, 1991:107), which coincides with Leech and Short's (2007:61) indication that the coordinator and takes priority over the adversative conjunction but even when the latter is expected. The two cases are syntagmatically and syntactically likewise but paradigmatically and semantically otherwise. Semantic nuances between the XX-YY lexical choices on the selection axis arouse curiosity on part of text consumers. Despite the lexical identity of the X-items above, they are semantically distinct and their distinction is generated by the concepts borne by their Y-opposites. Case $3 \mathrm{e}$ echoes the negative frameworks employed by cases 3a-c, featuring different lexemes framed by NOT X BUT Y rather than NOT X AND Y. The X-opposites laysa junāḥ/junāh 'no blame/blame' serve to draw attention to a primary pair of opposites, Y-members, ahta 'tum/ta 'ammadat 'do by mistake/do on purpose'. The implication 
is that wrongdoers will not be blamed or punished for any wrong they did by mistake before the prohibition, but will be blamed or punished for the wrongs they did on purpose after the prohibition-an implication strengthened by prophet Muhammad's words "I do not fear what you do by mistake, but I fear what you do on purpose" (cf. al-Zamahsharī, 1998 [P5]:46-47). Ibn 'Āshūr (1984 [P21]:265) contends that negating the lexeme junāh 'blame' with laysa 'not' entails a case generalization, confirming the rule of not specifying a general because of the specificity of its cause.

6.2.3 Canonical opposites as ancillary sharpeners of less canonical ones in a coordinated frame

The cases given below constitute PARADIGM II in which the A-pair words are conventional opposites serving as ancillaries for signaling less conventional but absolutely essential opposition between the Bpair ones in coordinated constructions.

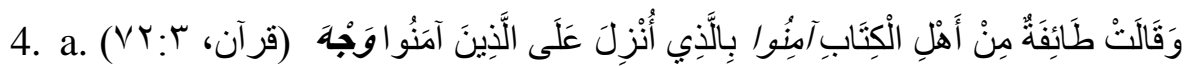

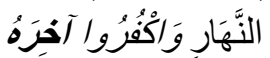

b. Some of the People of the Book said, 'Believe in what has been revealed to these believers [the Muslims] at the outset of the day AND disbelieve at the end of it. (Q, 3:72)

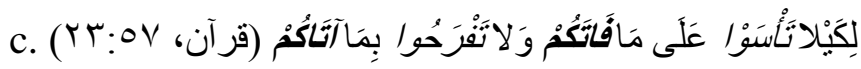

d. So you will NEITHER grieve for what you miss NOR gloat over what you gain. (Q, 57:23)

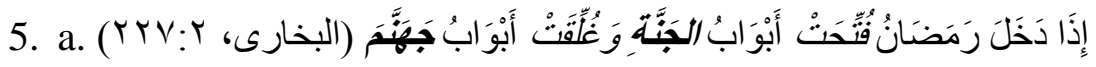

b. When Ramadan comes, the gates of paradise will have been opened AND the gates of hellfire will have been closed. (SB, 2:227)

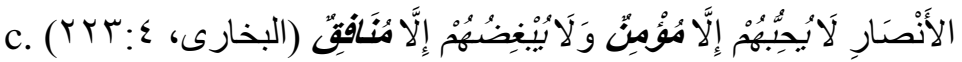


d. The Supporters are NEITHER loved by anyone except a believer NOR hated by anyone except a hypocrite. (SB, 4:223)

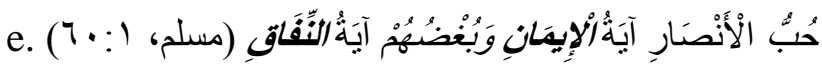

f. Love of the Supporters is a sign of belief AND hatred of them is a sign of hypocrisy. (SM, 1:60)

Case 4a describes, in a form of flashback, a party of the People of the Book who vainly plot to befool the Muslims to whom the Qur'an was revealed, by planning to believe in the revelation at the beginning of the day and to disbelieve at its end with the hope that the Muslims might desert their faith. The canonical A-pair opposites 'āminū/'ikfurū 'believe/disbelieve' are recruited to draw attention to less canonical Bpair opposites wajh/'ähir 'outset/end' within an X AND Y frame, in which the focus is laid more on temporality of the action than on the action itself. The canonical opposite of the item 'āhir 'end' is 'awwal 'beginning'. Then why is the item wajh, not 'awwal, opposed to 'ähir? Al-Sha rāwī (1991:1539) establishes a semantic nuance and proposes an answer: the lexical choice wajh covers the day from early morning to noon and thus is more inclusive than the lexeme 'awwal. Case 4c joins a canonical pair of words ta 'saw/tafrah̄ū 'grieve/gloat' (A-pair) to point to a primary, but less canonical, pair of opposites fātakum/'atākum 'miss/gain' within a correlative NEITHER X NOR $Y$ framework, the function of which is to neutralize and moderate the states of Xness and Yness, i.e., neither to grieve over what is missed, nor to gloat over what is gained. Those who trust in God should take a neutral, moderate stance in times of difficulty or ease (cf. Ibn 'Āshūr, 1984 [P27]:412; al-Zamahsharī, 1998 [P6]:50).

In Case 5a, the prophet Muhammad passes to his followers a piece of information about Ramadan, during which the gates of paradise in heaven are opened and those of hellfire are closed. He does so by harnessing, within an X AND Y frame, ancillary canonical opposites futtihat/gulliqat 'be opened/closed' to define more important, but less 
canonical, nominal opposites al-janna/ jahannam. The holonym al$n \bar{a} r$ 'fire', which is the canonical opposite of al-janna 'paradise', is replaced with a meronym thereof, i.e., jahannam. Fire falls into darakāt 'descending abysses', of which the seven-doored jahannam is said to be one daraka (cf. al-Majlasī, n.d. [P8]:289), whereas paradise rises into darajāt 'ascending ranks'. Cases 5c and 5e show prophet Muhammad's love and respect for the Supporters who staunchly helped him with his mission after his emigration from Mecca to Medina. Both cases share the theme and motif but differ in style. While case 5c coordinates canonical verbal ancillaries yuhib/yubgid 'love/hate' in an excepted NEITHER X NOR Y frame to signal a central opposition between less canonical nominal opposites mu'min/munāfiq 'believer/hypocrite' in the nominative case, case $5 \mathrm{e}$ coordinates canonical nominal ones hub/bugg d 'love/hatred' in an X AND $\mathrm{Y}$ frame to establish a crucial opposition between also less canonical nominal opposites al- 'imān/al-nifāq 'belief/unbelief' in the genitive case. The former case reveals that only the believers love the Supporters and only the hypocrites hate them; the latter case shows love and hatred of the Supporters as signs of belief and unbelief, respectively. In the Qur'an (3:167), hypocrisy is proved to be closer to unbelief than belief and, therefore, entails that the hypocrites and their superordinates, the unbelievers, hate the Supporters.

\subsubsection{Canonical opposites as ancillary sharpeners of less canonical ones in a negated frame}

The cases below expand PARADIGM II that includes canonical opposites serving as pointers to less canonical ones in negated structures, accommodating two main frameworks, X AND NOT Y or NOT X BUT Y.

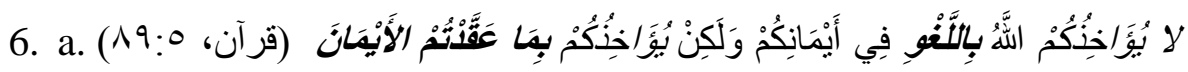


b. God does NOT blame you for thoughtlessness in your oaths, BUT blames you for the binding oaths you make. (Q, 5:89)

Case 6a features canonical verbal opposites $l \bar{a}$ yu'āhidukum/yu'āhidukum 'not be blamed/be blamed' that are manipulated in a negated NOT X BUT Y structure to signal a less canonical opposition between two types of oath: al-lagiw fi 'aymānikum/'aqadtum al-'aymān 'thoughtless oaths/solemnize the oaths' (phrase/clause). The two types can be put as al-yamin allagis/al-yamin al-mun 'aqada, which precipitate a fatwa of redemption or expiation, respectively. The implication is that intentionality is one basis for fatwa in Islamic sharia and oath makers shall be blamed only for solemn or binding oaths, not for unconscious or unintended ones (cf. al-Zamahsharī, 1998 [P2]:287). Hence, they are told to observe their oaths and keep them to a minimum.

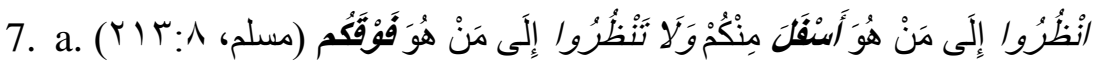

b. Look at the one who is inferior to you AND do NOT look at the one who is above you. (SM, 8:213)

Case 7a reverses the syntactic frame NOT X BUT Y that starts with a negative imperative favoring the coordinator lākin 'but' and turns it into the frame $\mathrm{X}$ AND NOT $\mathrm{Y}$ that starts with a positive imperative, preferring the coordinator $w a$ 'and' and hosting canonical A-pair opposites 'unzurū/lā tanzurū 'look/not look' to signal opposition between less canonical B-pair opposites 'asfal/fawq 'inferior/above'. When de-contextualized or co-occurring in a nonhuman context, the canonical opposite of 'asfal 'down' is 'a ' $\bar{a}$ 'up' and that of fawq 'above' is taht 'below'. The prophet Muhammad, however, interchangeably uses the members of either pair in a human context to attenuate canonicity, whereby his followers are told to compare themselves with whoever is inferior, not superior, to them in order not to turn ungrateful for God's blessing bestowed on them. If one looks at those who are above, envy might creep into his 
or her heart and he or she may be eaten with jealousy. The remedy would then be to look at those who are below (cf. al- 'Asqalānī, n.d. [P11]:323) to remain satisfied with and thankful for God-given blessings.

\subsubsection{Canonical opposites as ancillary triggers of noncanonical ones in a coordinated frame}

The following cases form PARADIGM III in which a conventional pair of opposites is used to trigger a nonconventional opposition between another more important pair, the members of which are not interpreted as opposites in neutral contexts but are treated as such in specific ones.

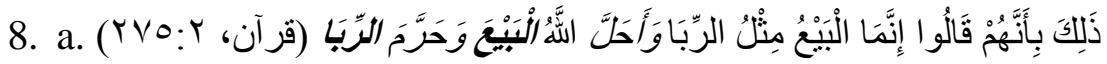

b. That is because they say, 'Trade and usury are the same,' but God has allowed trade AND forbidden usury. (Q, 2:275)

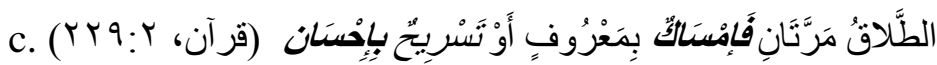

d. Divorce can occur twice, so hold (your wives) by right OR release (them) with grace. (Q, 2:229)

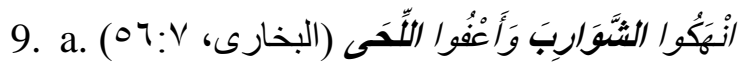

b. Cut moustaches AND keep beards.

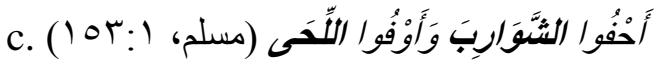

d. Shave moustaches AND grow beards.

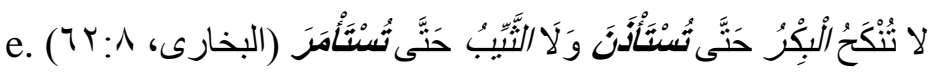

f. NEITHER the virgin must be married until she is asked for permission NOR the matrimonially deflowered until she is asked for command.

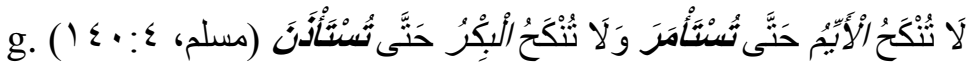

h. NEITHER the single must be married until she is asked for command NOR must the virgin until she is asked for permission. 
Case 8a conjoins the canonical A-pair 'ahalla/harrama 'allow/forbid' in an X AND Y framework to trigger an opposition between noncanonical, contextually pertinent, B-pair members albay /al-riba ' 'trade/usury' to reject their equivalence that is claimed by usurers and state their contrariety: trade is halal while usury is haram. This verse presents the reason why usurers would be like devilpossessed people falling and rising from time to time (cf. alZamahsharī, 1998 [P1]:506). Divorce is the main theme of case 8c, which coordinates the canonical A-pair members 'imsāk/tasrīh 'hold/release' in an X OR Y frame to give the divorcé, the divorcing man in most cases, a choice from the noncanonical, rather synonymous, B-pair members, ma 'rüff'ihsān 'right/grace', triggering in between a noncanonical opposition instead of their synonymy. The ideological purport is to issue a warning against oral play with divorce words, as the divorcing person has the option to rightfully hold back his or her divorcé(e) or kindly release him or her if the divorce happens twice. If divorce took place thrice, the divorcée would have to consummate marriage with another man before giving herself back to her ex-divorcé. Her marriage with the other man must be done without backdoor arrangements or agreements between the three parties (cf. al-Zamahsharī, 1998 [P1]:443). Ibn 'Āshūr (1984 [P2]:407) draws an insightful distinction between $m a$ ' $r u ̄ f$ and 'ihsān. The former is given more priority over the latter as it is more recommended in the Islamic jurisprudence. The latter is a literal and metaphorical opposite of the former. The former is so-called because it is what people know in all their dealings, such as the rights laid by the Islamic religion and the rights laid by social convention and tradition. Ma'rüf means establishment of an excellent connubial relationship and provision of conjugal rights, while ihsān means provision of financial rights only.

Cases 9a,c cite the prophet Muhammad as giving a command to his followers to do the opposite of what the polytheists have been doing 
with their moustaches and beards: to shorten their moustaches and lengthen their beards. Two distinct pairs of canonical antonyms (Apairs), 'anhikū/a 'fū 'cut/keep' and 'ahfü/'awfü 'shave/grow', are used to trigger opposition between noncanonical B-pair members alshawārb/al-lih̄a 'moustaches/beards' in an X AND Y frame. Simultaneity is syndetically imparted to the two actions by the coordinator 'aw 'and'. Cases 9e,g draw a marriage-contracting distinction between the A-pair members al-bikr 'virgin' and al-thayyib 'deflowered' or al-'ayyim 'single' in a NEITHER X NOR Y framework: an unspoken permission (silence gives consent) should be taken from the never-married virgin to get her married; a spoken command must be sought from the marriageable single (widow or divorcee). The virgin can express her consent to the marriage proposal in silence; the widow or divorcee necessarily in words (al- 'Asqalānī, n.d. [P9]:191-192); al-Nawawī, 1987 [P9]:203). The bikr and thayyib are opposed on virginity dimension; 'ayyim and bikr on marriageability dimension.

\subsubsection{Canonical opposites as ancillary triggers of noncanonical ones in a subordinated frame}

Cases home to this class belong to PARADIGM III and include pairs of conventional opposites that trigger other oppositions between nonconventional pairs in a complex structure involving two clauses: a dependent clause appended asymmetrically to a main clause by means of a subordinator, as if, when, since, and so forth. This class is labeled 'subordinated antonymy' (Hassanein, 2013a) and 'subordinated opposition' (Hassanein, 2018).

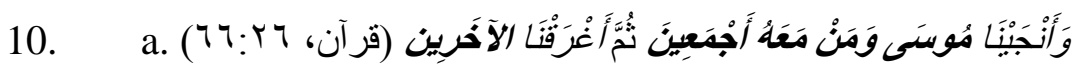

b. We saved Moses and all his companions; THEN We drowned the others. (Q, 26:66) 
Case 10a logs the co-occurrence of ancillary canonical A-pair antonyms 'anjaynā/agraqnā 'save/drown' within a temporally subordinated X THEN Y framework to trigger an opposition between noncanonical B-pair members Musā wa man ma'ahu ajma īn/al'äharīn 'Moses and all his companions/the others'. The gist of the subordinate configuration marked by the Arabic item thumma 'then' is to signify sequential order and intervallicity between the act of saving prophet Moses and all his companions and the act of drowning Pharaoh and all his followers in the Red Sea. The divine We asserts that it all happened by an act of God.

\subsubsection{Canonical opposites as ancillary triggers of noncanonical ones in an interrogative frame}

Cases attributed to this category exemplify PARADIGM III and comprise canonical opposites (A-pair) serving as triggers of an opposition between noncanonically opposed ones (B-pair). The triggering ancillaries and the triggered opposites co-occur within coordinate, interrogative constructions dubbed "interrogative antonymy" (Murphy and Jones, 2008:218), "disjunctive antonymy" (Muehleisen and Isono, 2009:2197), and "binarized option" (Davies, 2012:69). Of these three labels, "interrogative" serves most here, being a coverall term for conjunction and disjunction (or optionality).

11.

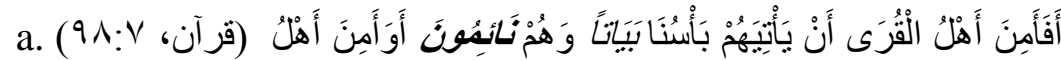

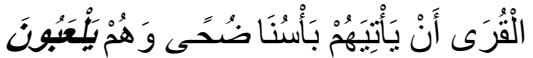

b. Do the people of these towns feel secure that Our punishment will not come upon them by night, while they are asleep? OR do the people of these towns feel secure that Our punishment will not come upon them by day, while they are at play? (Q, 7:98)

Case 11a disjoins the times at which God's punishment would befall the townspeople who arrogantly think that they are safe from it: bayātā 'by night' which is a time for nawm 'sleep' or $d u h \bar{a}$ 'by day' which is a time for la 'ib 'play'. Both periods are said by Ibn 'Āshūr 
(1984 [P9]:23) to be usually times for rest. It employs a disjunctively interrogative construction X OR Y? in which the canonical A-pair items bayātā/duhā 'around midnight/around forenoon' serve as adverbs of time to bring noncanonical B-pair members $n \bar{a}$ 'imūn/yal 'abūn 'asleep/at play' into opposition. The motif is to convey God's categorical denial of the townspeople's certainty of being safe from affliction during these two specific times. God selects these times in particular because during them townspeople are either sleeping or playing, respectively. The bayāt transpires after work to have rest and the $\underline{d} u h \bar{a}$ happens before work to have fun (Ibn 'Āshūr, 1984 [P9]:23). A person in his or her right mind must beware God's guile as warriors beware enemy's ambush, night attack and assassination (al-Zamahsharī, 1998 [P2]:480).

\subsubsection{Canonical opposites as ancillary triggers of noncanonical ones in a negated frame}

The two cases below feature canonical pairs of opposites as triggering an opposition between noncanonical ones in negated structures, whereby one B-opposite is negated and the other is affirmed.

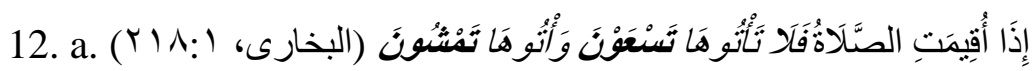

b. If prayer(s) started, do NOT come to it running, BUT come to it walking. (SB, 1:218)

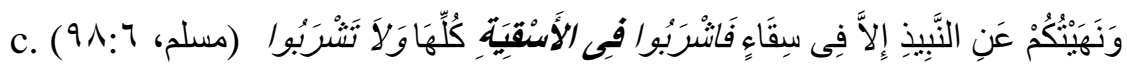
مُسْكرًا

d. I prohibited you from (drinking) wine except in water skins, so drink in all water skins and do NOT drink any alcoholic liquor. (SM, 6:98)

Case 12a conveys a prophetic prohibition of a pattern of behavior potentially noticed beforehand by the prophet Muhammad, a command to his followers not to run but to untiredly walk to mosque to perform what is left and complete what is missed. In doing so, the 
prophet proscribes the improper behavior in the negative imperative and prescribes the proper one in the positive imperative, using the canonical A-pair items $l \bar{a}$ ta 'tūh $\bar{a} /$ 'i 't $\bar{u} h \bar{a}$ 'not come/come' as ancillary triggers of opposition between noncanonical B-pair ones tas 'awna/tamshūn 'run/walk'. The syntactic framework is NOT $\mathrm{X}$ AND Y: do NOT come to prayer running AND come to it walking in a comfortable manner. Case $12 \mathrm{c}$ reverses the preceding frame, thus employing an X AND NOT Y framework within which conventional A-pair members 'ishrabū/lā tashrabū 'drink/not drink' co-occur to create an opposition between what to drink and what not to drink, the nonconventional B-pair members $f \grave{\imath}$ al-'asqiya/muskirā 'in water skins/alcoholic liquor'. The Muslims, who were not allowed by the prophet to drink from any water skin, are then allowed to drink from all water vessels but not to drink any alcoholic liquor (cf. al-Nawawī, 1987 [P1]:185).

\subsubsection{Less canonical opposites as ancillary signalers of canonical ones in a coordinated frame}

There are cases that feature less canonical ancillary opposites (A-pair) that serve to sharpen a canonical opposition between canonical ones (B-pair) in coordinative frames. These cases form PARADIGM IV.

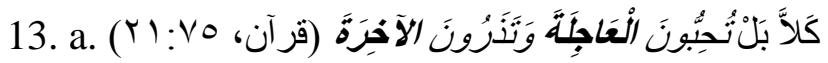

b. Truly you love this passing life AND leave the life to come. $(\mathrm{Q}$, 75:21)

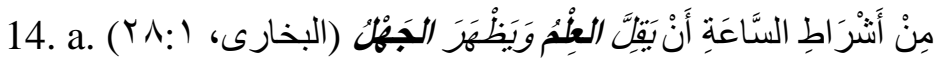

b. Among the signs of the Hour are the decrease in knowledge AND the appearance of ignorance. (SB, 1:28)

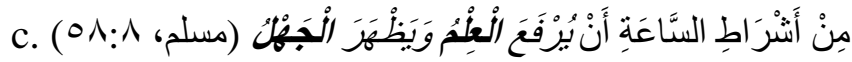

d. Among the signs of the Hour are the removal of knowledge AND the appearance of ignorance. (SM, 8:58) 
Case 13a conjoins the same less canonical A-pair items tuhibbūna/tadarūna 'love/leave' in an X AND Y frame to confirm a canonical opposition between other B-pair members al- 'ajjila/al-'āhira 'this passing life/life to come', differing only in cliticization. The conventional opposite of tuhibbüna is takrahūna 'hate', but it is replaced with tadarūna 'leave' to show how human beings in general show absolute concern for ephemeral pleasures of this life that sooner end and leave aside or behind those of the afterlife that will never end.

Cases 14a,c foreshadow two of the minor signs of the advent of the Hour that herald the apocalypse: qillat al-ilm 'decrease in knowledge' and zuhūr al-jahl 'appearance of ignorance'. SB and SM share the second A-pair member yazhar 'appear' to which the first less canonical A-pair members yaqil/yurfa' 'decrease/be removed' are respectively opposed. The canonical opposite of the seed item yazhar 'appear' is yahtafi 'disappear'. However, two less canonical opposites are employed instead to work together with the seed A-pair word on augmenting the canonical opposition between the B-pair opposites al'ilm/al-jahl 'knowledge/ignorance'. The implication is that knowledge will gradually decrease until it is completely removed with the deaths of its holders, and ignorance will prevail (cf. al-'Asqalānī, n.d. [P1]: 178).

\subsubsection{Less canonical opposites as ancillary sharpeners of less canonical ones in a coordinated frame}

This section constitutes PARADIGM V in which less conventional Apair opposites serve to sharpen and augment opposition between less conventional B-pair members in a coordinative construction.

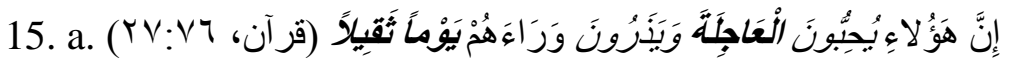

b. These (people) do love this passing life AND leave behind a Heavy Day. (Q, 76:27) 


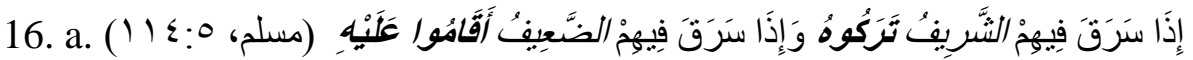
الْنَعَّ

b. IF the noble among them steals, they leave him, AND IF the weak among them steals, they punish him. (SM, 5:114)

Case 15a reveals a characteristic feature of those who have no faith in God and describes their egos as cherishing this passing life and relinquishing a heavily loaded Day, Doomsday. The A-pair members yuhibbüna/yadarūna 'love/leave', the conventional opposites of which are respectively yakrahūna/yattahidūna 'hate/take', are brought together in a nonconventional opposition to trigger an opposition between unconventionally opposed B-pair members al- 'àjila/yawman thaqūlā 'passing life/heavy Day', whose conventional opposites are al-'ähira/yawman hafífā 'life to come/light day'. The holonym al-'ähira, the canonical opposite of al- 'ajila (cf. $\mathrm{Q}, 75: 21$ ), is taken out and replaced with a part or a meronym thereof, yawman thaqīla. The purpose is to shift the propositional content of the verse from pace to weight. The entire ephemeral life cherished by the unfaithful has a light weight compared with the heavy Doomsday that spans between one and fifty thousand years in our reckoning (cf. Q, 22:47; 32:5; 70:5).

Case 16a conjoins the less canonical A-pair members al-shariffalda 'if 'the noble/the weak' in an IF X AND IF Y frame to sharpen a less canonical opposition between the B-pair members tarakūh/'aqūmū 'alay al-hadd 'leave/punish'. The canonical opposites of the former A-pair items are respectively al-wadī/alqawiyy 'the ignoble/the strong', whereas those of the latter pair members are 'ahad $\bar{u} h /$ samah $_{\bar{u}} h$ 'take/forgive'. This prophetic tradition transpired in reaction to an intercession made by 'Usāma b. Zayd to the prophet Muhammad in favor of a noble Qurayshite woman, charged with theft, to save her from God's penalty for the theft. In respect of God's penalties, the prophet flatly refused and delivered an immediate speech to his people about how the former nations were 
destroyed because of their social discrimination between the noble and the ignoble. Penalties in their times were applicable only to the weak and that was why the prophet swore to cut off the hand of his daughter, Fātima, if she stole. Thus the prophet meted out justice and ordered that the woman's hand be cut off. Justice must be done in any case and intercession is totally forbidden when it relates to a divine commandment (cf. al-Nawawī, 1987 [P11]:186).

\subsubsection{Less canonical opposites as ancillary sharpeners of less canonical ones in a subordinated frame}

Case 17 a replicates PARADIGM V in which a pair of opposites is temporally subordinated to another pair that co-occurs within the syntactic frame IF X THEN IF Y.

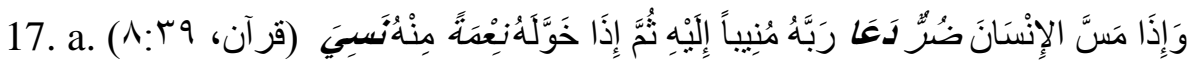

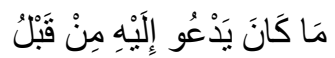

b. IF man suffers an affliction, he invokes his Lord and turns to Him. THEN IF he has been granted a blessing from God, he forgets the One he had been praying to. (Q, 39:8)

Case 17a features less canonicity of oppositions within a subordinated framework IF X THEN IF Y bringing together less conventionally opposite A-pair members durr/ni 'ma 'harm/blessing' to hone another less canonical opposition between the B-pair members da 'ä/nasiya 'invoke/forget'. Both pairs are employed to describe how human beings supplicate God in times of trouble and forget about their supplication to Him if He turns their trouble into a blessing. The ideological view is that God is remembered in times of difficulty and forgotten in times of ease. The canonical opposites of durr/ni 'ma are naf'/niqma 'benefit/curse' and that of nasiya 'forget' is tadakkara 'remember' omitted in favor of a less canonical opposite da' $\bar{a}$ 'invoke'. The deep structure of this syntactic framework is evocative of transitional opposition marked by a transitional shift from a state of distress to a state of comfort. 

Bulletin of the Faculty of Arts Volume 80 Issue 8 October 2020

6.2.12 Less canonical opposites as ancillary triggers of noncanonical ones in a coordinated frame

Case 18a establishes PARADIGM VI, within which two less canonical opposite members co-occur to trigger a noncanonical opposition between two other members not interpreted as opposites in neutral contexts.

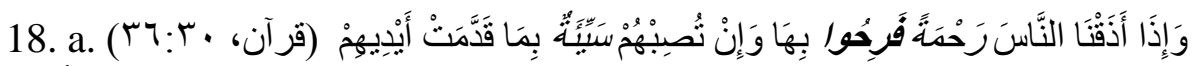
إِذَا هُْْ بَقْنَطُونَ

b. IF We give people a taste of mercy, they gladden AND IF a bad deed happens to them, because of their own actions, they despair. (Q, 30:36)

Case 18a coordinates less canonical A-pair opposites rahma/sayyi 'a 'mercy/bad deed' in the syntactic frame IF X AND IF $\mathrm{Y}$ to trigger a noncanonical opposition between B-pair members farihü/yaqnațūn 'gladden/despair'. The canonical opposites are 'ad āb/hasana 'torment/good deed' and yaḩzanū/'amilū 'sadden/hope', respectively. God manipulates the less canonical and noncanonical opposites to clarify how people become happy when they taste a bit of mercy but fall into despair of God's mercy if something bad brought about by their own sins happens to them. God wants people to show patience rather than despair in times of difficulty (cf. al-Zamahsharī, 1998 [P8]:580).

\subsubsection{Less canonical opposites as ancillary triggers of noncanonical ones in a subordinated frame}

Case 19a uses a subordinated structure to host a less canonical pair of opposites serving as ancillaries for triggering a noncanonical opposition between members of another pair.

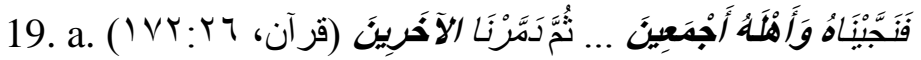

b. We saved him and all his family ... THEN We destroyed the others. (Q, 26:172) 
Case 19a replicates PARADIGM VI within a subordinated environment, X THEN Y, housing a less canonical pair of opposites najjaynā/dammarnā 'save/destroy' (A-pair) used as ancillaries for the triggering of another noncanonical opposition between items of a Bpair $h u$ wa 'ahlahu/al-'äharin 'he and his family/others' interpreted oppositionally only in conflictual contexts. The verse weaves an analepsis, a flashback, of prophet Lot's time when men in his community developed homosexual tendencies towards one another and towards his guest angels and refrained from straight heterosexual relations with their women. As a result, God saved the prophet Lot and his family but then ruined all the other corrupts. The subordinator thumma 'then' does impart temporal precedence to one action over the other, being representative of sequential order of two actions with an interval in between (Ibn 'Āshūr, 1984 [P19]:181). What follows thumma is subsequent to what precedes it: X THEN Y, AFTER X, Y and BEFORE Y, X.

\subsubsection{Less canonical opposites as ancillary triggers of noncanonical ones in an interrogative frame}

The following case also typifies PARADIGM VI, retrieving and replicating a less oppositional canonicity between the members of two opposed pairs.

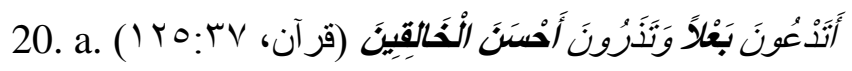

b. HOW can you invoke Baal AND leave the Best Creator? (Q, $37: 125)$

Case 20a manipulates four members that are not treated by the native speakers of Arabic as conventional opposites but as less conventional ones: tad' ūna/tadarūna 'invoke/leave' and Baal/'ahsana al-ḩāliqīn 'Baal/Best Creator'. The conventional antonym of tadarūna 'leave' is commonly tattahidüna 'take'. The propositional focus of the former pair is on the act of invocation or supplication rather than divination. God, the Best Creator, deprecatingly interrogates the 
townspeople's logic of their prayers to Baal, an idol after whom today's city of Baalbek has been named (cf. al-Zamahsharī, 1998 [P5]:229), and their abandonment of the Best Creator. The interrogation, $\mathrm{X}$ and $\mathrm{Y}$ ?, serves as a rhetorical question not intended for the elicitation of an answer, but for despise and disapproval of their practices.

\subsubsection{Noncanonical opposites as ancillary signalers of canonical ones in a coordinated frame}

PARADIGM VII includes noncanonical pairs of opposites whose function is to signalize oppositions between canonical pairs in coordinate environments, which are the foci of contrarieties.

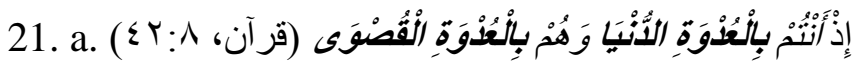

b. Remember when you were on the near side of the valley AND they were on the far side. (Q, 37:125)

Case 21a uses the syntactic frame $\mathrm{X}$ AND $\mathrm{Y}$ to coordinate pronominal deictics, a second-person plural pronoun 'antum 'you' and a third-person plural pronoun hum 'they', as noncanonical opposites pointing to a more important opposition between a canonical pair of opposites al-'udwatu al-duniā/al-'udwatu al-qușwā 'near side/far side'. God reminds the Muslims of the critical battle-day of Badr when they were positioned in a location lower and weaker than that of their polytheistic enemy (al-Zamahsharī, 1998 [P2]:585). Although the geographical conditions of the battle were in favor of their enemy and provided grounds for the latter's victory, God turned the tables on the enemy and led the Muslims to a resounding victory. In return for this favor, the Muslims should remain grateful and thank God's blessing upon them by doling out one-fifth of war spoils or booties to Him, to the prophet Muhammad, to the relatives, to the needy and to the wayfarers.

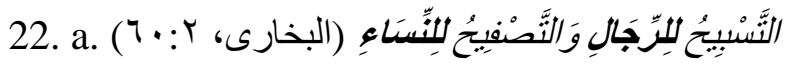


b. Glorification (of God) is for men (to do) AND applause is for women (to do). (SB, 2:60)

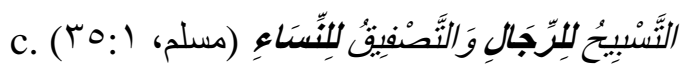

d. Glorification (of God) is for men (to do) AND clapping is for women (to do). (SM, 1:35)

Case 22a inserts a pair of incompatible, but not contrary, words, al-tasbīh/al-tasfịh 'glorification/applause', into a noncanonical opposition to play an ancillary role in signaling and confirming an opposition between two other canonical opposites, al-rijāl/al-nis $\bar{a}$ 'men/women'. This prophetic tradition stemmed from the prayers' normative practice of clapping their hands to attract their imam's attention to a ritual he forgot to do during prayers. The prophet Muhammad condemned that practice on this particular occasion, prescribing that glorification of God with the commendatory Arabic formula subhâna al-lāh 'Glory be to God' must be the manly activity, whereas applause must be the womanly activity. Here the focus is placed more on the who (the actor) than on the what (the act) in reply to questions, such as 'Who should glorify' and 'Who should clap', not 'What men or women should do'. The tradition has a corrective purpose which is achieved by means of a coordinated, ancillaryinduced, frame X AND Y. Case 22c replicates the same framework on the syntagmatic axis, sharing and retrieving all the lexical choices on the paradigmatic axis except one: al-tașiq 'clapping' has been selected in substitution of al-tasfih 'applause', arousing an overwhelming curiosity on part of the receivers to find out the differences between the two apparently synonymous pair al-tasfih $/$ altasfiq. Do both lexemes carry the same or different sense in the language system and the same or different reference between the language and the world? According to al-Suyūtī (1986 [P2]:79), there is a referential nuance between the two terms, whereby the former refers to two different forms of handclap: (a) the two right-hand fingers against the left-hand palm and (b) the back of either hand 
against the palm of the other. The latter refers to the normal handclap in which the two-hand palms are stricken together, as in Figure 4.
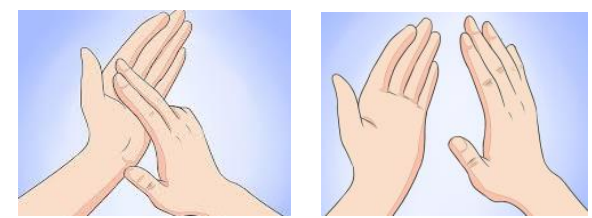

Figure 4 Pictorial distinction between al-tasfịh and al-tasfiq , respectively

\subsubsection{Noncanonical opposites as ancillary signalers of canonical ones in a negated frame}

PARADIGM VII also includes noncanonical pairs of opposites serving to signal oppositions between canonical pairs in multiple negated frameworks.

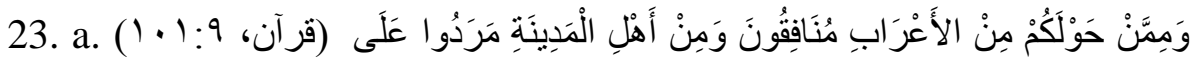

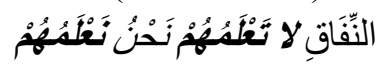

b. Some of the desert Arabs around you are hypocrites, as are some of the people of Medina- they are obstinate in their hypocrisy. You [Prophet] do NOT know them; We know them. (Q, 9:101)

In Case 23a, God confirms that some desert Arabs and Medinans were obstinate hypocrites unknown to the prophet Muhammad. The prophet did not know them; only God knew them. Such hypocrites were promised a frequent torment in their worldly lives and a greater torture in the afterlife (Ibn 'Āshūr, 1984 [P11]:20). The ideological point is to display hypocrisy as an abhorrent human characteristic meriting severe punishment and as an inner trait known only to God. The syntactic frame favored here is the NOT X, Y frame which hosts a noncanonical pair of opposites 'anta/nahnu 'you/We' serving as pointers to a canonically opposite pair $l \bar{a}$ ta 'lamhum/na 'lamhum 'not know/know'. 


\subsubsection{Noncanonical opposites as ancillary signalers of canonical ones in an interrogative frame}

PARADIGM VII further comprises a noncanonical pair of opposites signalizing an opposition between the members of another canonical pair in an interrogative construction.

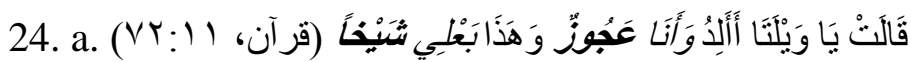

b. She said, 'Alas for me! How am I to bear a child when I am an old woman, and my husband here is an old man? (Q, 11:72)

Case 24a employs the X AND Y framework to coordinate a noncanonical pair of opposites 'anā/had̄ $b a$ ' $\bar{l}$ ' $I /$ this husband' to signal a canonical opposition between another pair of words 'ajüz/shayhāa 'old woman/old man'. Although both pairs stand out in a coordinative structure, interrogation as a discourse function overrides coordination here and this explains why this case has been assigned to the interrogative rather than coordinative function, a rigorous argument presented by some other scholars in their studies of antonymy across different languages (e.g., Jones, 2002, 2006; Murphy and Jones, 2008; Muehleisen and Isono, 2009; Murphy et al., 2009; Hassanein, 2013a). The rhetorical purposes of the prophet Lot's wife's interrogation is to deem unusual, if not impossible, a case in which a child would be born to a rather old couple at the age of ninety-eight (al-Zamahsharī, 1998 [P3]:217). The news-bearing angels rejected her wonder by informing her, through a rhetorical question, that it is God's command.

\subsubsection{Noncanonical opposites as ancillary sharpeners of less canonical ones in a coordinated frame}

This section builds up PARADIGM VIII in which two lexemes are noncanonically opposed to sharpen an opposition between less canonically opposite words co-occurring in coordinative frames.

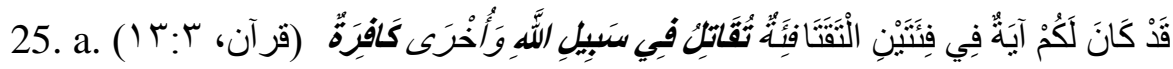


b. You have already seen a sign in the two armies that met in battle, one army were fighting for God's cause and the other were unfaithful. $(\mathrm{Q}, 3: 13)$

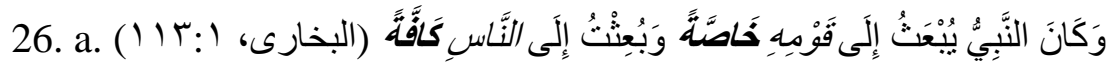

b. Each of the (former) prophets was sent to his own people in particular and $I$ was sent to all people in toto. (SB, 1:113)

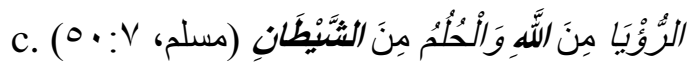

d. Vision (comes) from God and dream (comes) from Satan. (SM, $7: 50)$

Case 25a coordinates two noncanonical opposites $f i^{\prime} a /{ }^{\prime} u h r \bar{a}$ 'one army/the other' in an X AND Y frame to sharpen a less canonical opposition between two other opposites from different form classes, tuqātil fì sabīl al-lāh/kāfirā 'fight for God's cause/unfaithful' (verbal predicator vs. adjectival predicate). The canonical opposite of käfirā 'unfaithful' is mu'mina 'faithful'. God addresses unfaithful Quraishites and reminds them of the Battle of Badr during which $\mathrm{He}$ supported a Muslim army with invisible fighters against a polytheistic army and led them to victory (al-Zamahsharī, 1998 [P1]: 531). Case 26a employs the same coordinated syntactic frame to host a pair of noncanonical opposites al-nabiyy/'anā 'prophet/I' to serve an ancillary role in sharpening a less canonical opposition between members of another pair hașạa/kāfa 'in particular/in toto'. The canonical opposite of hașa a in particular' is 'äma 'in general'. The prophet Muhammad draws a contrast between him and his predecessors, stating that his predecessors were sent by God to separate communities while he, perhaps being the last or seal prophet, was God's messenger to all humanity. Case 26c reuses the same coordinate frame to bring the synonyms al-ru'yā/al-hulum 'vision/dream' into a noncanonical opposition to sharpen a less canonical opposition between the B-pair members al-lāh/al-shaytān 'God/Satan'. The canonical opposite of al-shaytān is al-malāk 
'Angel'. The less canonical God-Satan opposition is motivated and sharpened by the A-pair members al-ru'yā/al-hulum 'vision/dream', which are interpreted as being good and bad, respectively. This argument is further supported by other relevant prophetic traditions, which draw an opposition between good vision and dream (SB, 4:95) and between good vision and bad vision (SM, 7:51). These two traditions are not included here due to their impertinence to PARADIGM VIII.

\subsubsection{Noncanonical opposites as ancillary triggers of noncanonical ones in a coordinated frame}

This is PARADIGM IX in which pairs of unconventionally opposed lexemes (A-pairs) co-occur within coordinated frameworks to play ancillary roles in triggering oppositions between other nonconventional pairs (B-pairs).

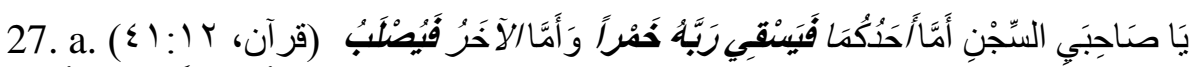

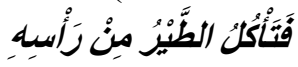

b. Fellow prisoners, AS FOR one of you, he is going to serve wine to his king AND AS FOR the other, he is going to be crucified, then birds are going to eat from his head. (Q, 12:41)

Case 27a features the notion of binary oppositions on Greimas's semiotic square (cf. Hassanein, 2009:40, 2013b:63-69) as an indispensable narrative tool in structural-cognitive semiotics, whereby narrative events progress in terms of a thematic binarity. The verse presents the prophet Joseph's interpretations of two visions given by his two prison inmates: one presses grapes into wine and the other carries bread above his head from which birds were eating. The prophet Joseph coordinates his interpretations within an AS FOR X AND AS FOR Y framework: as for one (i.e., the former), he would serve wine to his king and as for the other (i.e., the latter), he would be crucified and birds would be eating from his head. The A-pair 'ahadukmā/al-'āhar 'one/the other' functions as ancillary 
noncanonical opposites to trigger a more interesting noncanonical opposition between the B-pair members yasqī/yuṣlab 'serve/be crucified'.

\subsubsection{Noncanonical opposites as ancillary triggers of noncanonical ones in a negated frame}

This is an extension of PARADIGM IX which includes noncanonical pairs of opposites co-occurring in negated frameworks to trigger oppositions between more important noncanonical pairs of opposites.

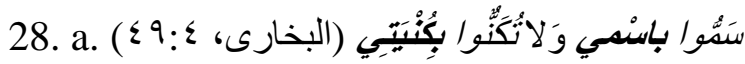

b. Name after my name AND do NOT nickname after my nickname. (SB, 4:49)

Case 28a is a typical case of noncanonicity, a phenomenal feature of antonymy or opposition in which noncanonical A-pairs of opposites co-occur to trigger a catchier opposition between noncanonical B-pairs. A negated framework X AND NOT Y hosts the noncanonical A-pair members sammū/tukannū 'name/nickname' in an ancillary manner to create an unexpected opposition between the noncanonical B-pair members 'ismī/kunyatī 'name/nickname'. The prophet Muhammad is teaching his followers to name their children after his name 'Muhammad' and not to nickname them after his nickname 'abā al-qāsim', as it is a patronymic unique to him. He was given this nickname because he used to be the distributer of rights and shares among his people (cf. al- 'Asqalānī, n.d. [P6]:217).

6.2.21 Duplicates, analogs, or (non)canonical opposites as ancillaries for oppositions between duplicates or (less or non)canonical ones in a coordinated frame

This constitutes PARADIGM $\mathrm{X}$ in which duplicate, analogous, canonical, or noncanonical lexemes are opposed in $\mathrm{X}$ AND $\mathrm{Y}$ coordinated frameworks to signal, sharpen, or trigger opposition between other duplicate, less canonical, canonical, or noncanonical items. Typical cases include the following: 


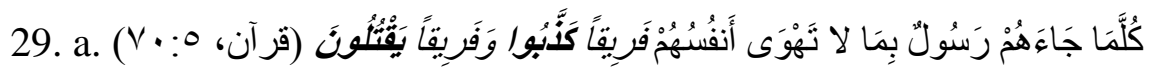

b. Whenever a messenger came to them with what they did not like, a group were disbelieved by them and a group were killed by them. (Q, 5:70)

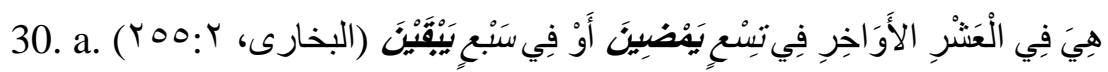

b. It is in the last ten days (of Ramadan), in nine that go by or in seven that remain. ( $\mathrm{SB}, 2: 255)$

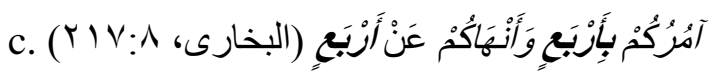

d. I prescribe four to you and proscribe four to you. (SB, 8:217)

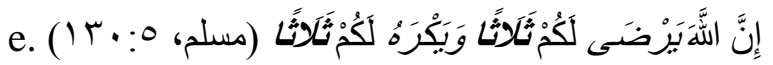

f. God accepts three for you and hates three for you. (SM, 5:130)

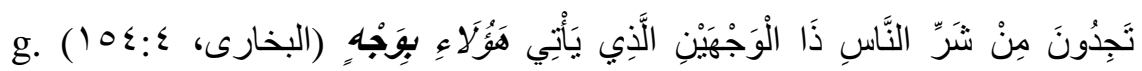
وَهَوُْلَاكِ بِوَجْهِ

h. Of the worst people you find is the two-faced one who comes to these with (one) face and these with (another) face. (SB, 4:154)

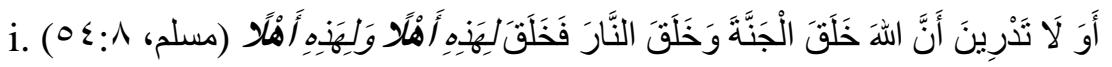

j. Do you not know that God created paradise and created fire, then He created for this (its) inhabitants and for this (its) inhabitants. (SM, 8:54)

All the cases above, except for Case 30a which uses the frame $\mathrm{X}$ OR Y, employ the frame X AND Y to a miscellany of ancillary configurations co-occurring in parallel structures peculiar to Classical Arabic. Case 29a conjoins A-pair duplicates farīqan/farīqan 'group/group' to trigger a noncanonical opposition between the B-pair members kad $\underline{d} a b \bar{u} / y a q t u l \bar{u} n$ 'disbelieved/kill', the canonical opposites of which are saddaqū/yuhyūn. God describes the Israelites as a community accustomed to disbelieving some of their God-sent prophets and killing some others.

Unlike its all fellow cases in the paradigm, Case 30a manipulates the syntactic frame X OR Y that serves an exclusively disjunctive 
purpose, whereby the occurrence of $\mathrm{X}$ annuls the occurrence of $\mathrm{Y}$. The prophet Muhammad sets Laylata al-Qadri 'The Night of Glory' in time during the sacred month of Ramadan, either in tis 'in 'nine' (an A-pair member) that pass by 'yamḍin' (a B-pair member) or in sab in 'seven' (an A-pair member) that remain 'yabqayn' (a B-pair member). The ideological significance is that it can occur either in the 29th night or the 23rd night (cf. al-'Asqalānī, n.d. [P4]:260). The A-pair members tis 'in/sab in 'nine/seven' function as ancillary analogs (specifiers or quantifiers) to point to a canonical opposition between the B-pair ones yamdīn/yabqayn 'go by/remain'. Case 30c features a canonical A-pair, 'āmurukum/'anhākum 'prescribe/proscribe', triggering an opposition between duplicated specifiers 'arba '/arba' 'four/four'. Canonical oppositionality is projected onto such quantifying duplicates by the B-pair members that stand together as canonical opposites in all contexts. Case 30e does exactly the same as Case 30c, with the difference that the former's B-pair items thaläthan/thalāthan 'three/three' are cast into opposition by the less canonical A-pair opposites yardā/yakrah 'accept/hate'. The canonical opposites of the latter pair are yarfud//yuhib 'reject/love', respectively. Case $30 \mathrm{~g}$ identifies one of those worst people as a double-faced person, a double-dealer, who regularly shows two different faces to two different groups: noncanonical A-pair members ha 'ulä 'ha 'ulä' 'these/these' and noncanonical B-pair ones wajh/wajh 'face/face'. Both pairs are duplicates brought into a noncanonical opposition to broach hypocrisy. Case 30i features a dialogue between the prophet Muhammad and his wife ' $\bar{A}$ 'isha about the death of one of al-'Anșār's (Supporters') young children. ' $\bar{A}$ 'isha deems the deceased young boy to be a paradise inhabitant, metaphorized as a paradise sparrow, whereas the prophet takes a neutral stance towards the case and states that God has created paradise and fire (heaven and hell in Western culture) and created inhabitants for each (cf. al-Nawawī, 1987 [P16]:207). Case 30i replicates the same syntactic frame, X AND Y, 
of Case 30g and the same proximal deitics, with two main differences: (a) the A-pair in Case30i hosts proximal demonstratives in the singular-feminine forms hadihi/hadihi 'this/this', pointing back to the referents al-janna/al-nār 'paradise/fire', and (b) a canonical opposition is imparted to the B-pair duplicates 'ahlan/'ahlan 'inhabitants/inhabitants' by a canonical opposition between the antecedents and their proximal deictics.

\section{Conclusions}

In this study, I tried to expand the syntagmatic approach to antonymy and opposition by proving the derivability of canonically, less canonically and noncanonically opposed pairs of ancillary antonymy and providing case-based evidence for what Jones (2002), Murphy (2003), Davies (2012, 2013), Kostić (2016) and Hassanein (2018) explicitly or tacitly reveal about the profile of (ancillary) antonymy in discourse. Kostic (2016:5-8) argues that the relation of ancillary antonymy is predictable and derivable in appropriate contexts, with a variable degree of antonymity, however. In ancillary antonymy contexts, contextual dependency of (non)canonical pairs can be null $(0 \%$, canonical), partial $(50 \%$, less canonical), or total ( $100 \%$, noncanonical) in antonym constructs, i.e., antonym pairings generated in ancillary antonymy contexts (Kostić, 2015:153). These antonym constructs vary and include co-hyponyms or totally unrelated pairs of words, phrases and clauses. The canonical antonyms are linked both semantically and lexically, more entrenched in memory, and reinforced through linguistic experience. The less canonical ones are inherently contrastive if they fall into complementary distribution within the same meaning dimension. The noncanonical pairs are treated as opposites when they are used in binary contrastive contexts. To recap then, I argue that ancillary oppositions, particularly of the noncanonical type, generate contrastive relations in context, even when canonical or less canonical A-pair antonyms are not there. The (non)canonically related B-pairs may have no contrastive power at all 
out of context and it is the ancillary A-pair members which impart the contrastive potential to these noncontrastive pairs.

Ancillary antonymy appears in several guises that constitute ten paradigms in the three $\mathrm{CA}$ datasets under scrutiny. PARADIGMS I/II/III feature canonical A-pairs, whose function is to signal, sharpen or trigger oppositions between canonical, less canonical or noncanonical B-pairs, respectively. The three configurations strongly support Jones's (2002:46) arguments that if the B-pair has no innate element of opposition (i.e., noncanonicity), the A-pair generates an instantial contrast; if the B-pair already has a low level of innate opposition (i.e., less canonicity), the A-pair activates this latent contrastive potential; and if the B-pair already has a high level of innate opposition (i.e., canonicity), the A-pair confirms this contrast to the point of assigning antonymity. In this manner, B-pairs are increasingly pushed further up the scale of opposition by the A-pairs. PARADIGMS IV/V/VI include less canonical A-pairs, the functions of which are to signal, sharpen or trigger oppositions between (non)canonical or less canonical B-pairs. PARADIGMS VII/VIII/IX comprise noncanonically opposite A-pairs, which serve to point to, sharpen or trigger oppositions between canonical, less canonical or noncanonical B-ones. PARADIGM $\mathrm{X}$ that looks exclusive to CA unexpectedly brings into opposition duplicates (with same meanings), analogs (with same functions), synonyms (with similar meanings) and meronyms (with partitive meanings) to interchangeably oppose each other sometimes as A-pairs or B-pairs. Given that the A-pairs are more flexible than absolute as Jones (2002:53) puts it, "A-pairs are equally flexible in text because they are able to serve different roles in different Ancillary Antonymy sentences", the present study expands by taxonomy Jones's (2002) dyadic theory of ancillary antonymy. The taxonomy demonstrates the versatile nature of ancillarity and canonicity: the ancillary effect of the A-pairs and the contrastive power of the B-pairs vary to a greater or lesser degree in CA discourse 
and figure in an orthodox fashion, and their order is central to the information structure. Versatility of the two pairs is evidenced by the diversity of the categories outlined and exemplified from CA discourse. This versatility confirms the presence of universalities and particularities across languages and supports Jones's (2002:102) argument that corpus linguistics is not an exact science and antonyms are occasionally used in innovative ways about which generalizations cannot easily be made. This seems to be a result of using different approaches and methods in data collection and classification and also due to cross-linguistic peculiarities.

The remodeling of ancillary antonymy in this study offers the following contributions to the state-of-the-art research on the ancillarity of antonymy: (1) it introduces opposition as a more general and more inclusive term than antonymy, a practice according with Davies (2012:47) and with the Arabic equivalents al-tibāq and almuqābala, respectively, whereby the former signals opposition between necessarily opposite words while the latter points to opposition between opposites and non-opposites. (2) It supports Jones's (2002:46) argument for the full canonicity of A-pairs and shows that A- and B-pairs are interchangeably nudged up or down the scale of canonicity, up to full canonicity or down to noncanonicity. Kostić (2016:6) holds a similar view that many examples of ancillary antonymy affirm the existence of a scale between pairings that are strongly conventionalized as antonyms, pairings opposable in some contexts (co-hyponyms and latent co-hyponyms), and pairings for which it is difficult to think of a context in which they could be used as antonyms although those contexts undoubtedly exist. (3) The remodeling also presents the A-pair ancillaries in CA as signalers, sharpeners and triggers of B-pair oppositions, foregrounding Jones's (2002) ancillary theory. (4) It exclusively logs duplicates, analogs, synonyms and meronyms thrust into (non)canonical opposition. (5) It gives evidence for featuring oppositions between words, phrases, 
clauses and sentences (Davies, 2012, 2013) and between strings from different form classes (Fellbaum, 1995; Lobanova et al., 2010). (6) It presents new instances of ancillary opposition that show gradation from canonicity to noncanonicity and mutual unexclusiveness of these two compartments, supporting Davies's (2012:42) insight that the canonical status of opposition ranges in a gradable cline from canonical to noncanonical.

This study suffers from a number of limitations. First, it lacks a corpus-based approach to the phenomenon under investigation in terms of which lexicosemantic theories can objectively be challenged and updated. Second, the cases selected for qualitative analyses are all based on the investigator's intuitive and thus subjective choices according to which other cases can be claimed to be identically applicable. Third, similarly replicating studies are direly needed so that the conclusions drawn here can be safely generalized. In conclusion, this study strongly recommends the manual-automatic extraction of data, which Hsu (2015:53) argues for in identifying contrastive structures in text. The manual search is a plausible and indispensable method for mining and collecting ancillary oppositions in discourse, besides the automatic method. A number of corpus linguists support, besides the automatic search, the manual method of data extraction (cf. Adolphs, 2008:51; Dash, 2008:92; Mautner, 2009:44, among others). Both methods work in tandem to provide a full profile of ancillary opposition, just as quantitative and qualitative methods are valuable for profiling textual opposition (cf. Davies, 2012: 69). The automatic quantitative method is very valuable for mining (canonical and less canonical) ancillary antonyms while the manual qualitative method is necessary for gathering noncanonical oppositions that necessitate human intervention. Both approaches, manual and automatic or quantitative and qualitative, work complementarily rather than competitively. In this article, I rigorously tried to expand the syntagmatic approach to antonymy and opposition 
in previous studies as inspired by Jones (2002), magnifying the drivability of canonically, less canonically and noncanonically opposed relations in ancillary antonymy contexts. More work is required on how ancillary opposition functions across languages and how its effect is projected onto nearby expressions across different genres of discourse for ideological purposes. A better comprehension of the various aspects and guises of opposition in religious texts necessarily contributes to a better and more orthodox comprehension of the divine and human thoughts. Opposition plays a pivotal role in the genesis and exegesis of ideology in theology where argumentation and persuasion are central discursive goals. 


\section{Notes:}

(1) 'Opposition' (e.g., Mettinger, 1994; Davies, 2012, 2013) is a more technically appropriate term than 'antonymy' for contrasting lexemes, meanings and concepts which are seen as canonical, less canonical or even noncanonical opposites at and above word level. There are, nonetheless, other labels used alternatively in the literature on aspects of semantic opposition: antonymy (e.g., Cruse, 1976; Lehrer and Lehrer, 1982; Lyons, 1995; Jones, 2002; Murphy, 2003, among others), contrast (e.g., Murphy, 2003; Abdel Haleem, 2004) and antithesis (e.g., Bussmann, 1996; Abdul-Raof, 2006).

(2) It must be noted here that Hassanein (2013) quantified and exemplified ancillary antonyms that co-occur intraversially (i.e., within a verse), neglecting many others that co-occur interversially (i.e., between verses) and thus leaving a wide gap to be filled by the present study.

(3) Throughout the article, all the representative examples selected sporadically and randomly from the Qur'an and Hadith texts are followed by a complete citation, whereby Q and SB or SM (standing for Qur'an, Șahịh al-Buharī, or Sahīh Muslim, respectively) as well as verse/part and page numbers are given in parentheses. Transliterations and retranslations are provided in text wherever and whenever necessary to avoid any mistranslations that do not suit the purpose of the study. The translations are adapted from Abdel Haleem (2004). Here it must be noted that the analysis of ancillary oppositions is based on the Arabic texts, not on the translations the presence of which is only to make the Arabic texts intelligible to whoever cannot understand Arabic.

(4) 'Reversives' are directional opposites denoting motion or change in opposite directions between two states (cf. Cruse, 2006:50).

(5) 'Converses' are relational opposites whereby one opposite yields the same proposition as the other when the arguments are reversed, as in $\mathrm{X}$ above $\mathrm{Y}$ and $\mathrm{Y}$ below $\mathrm{X}$.

(6) A point beyond the scope of the study but worth noting relates to Abdel Haleem's translation of al-ladinna kafarū/al-ladiña ämanū into disbelievers/believers rather than who disbelieve/who believe, which perfectly suit the source text in terms of grammar and semantics. His choice depicts unbelief and belief as being permanent characteristics of the two opposed groups, whereas the should-be relativized items entail a shift in status from belief to unbelief or vice versa. This simple example may suffice to show why I adapt the translation and how ancillary opposition is a great challenge for the translator of CA texts and can impact their (un)translatability. This further point is open for future research and is not handled any more for reasons of space. 


\section{References}

Abdel Haleem, M., 2004. The Qur'an: A New Translation. Oxford University Press, Oxford.

Abdul-Raof, H., 2006. Arabic Rhetoric: A Pragmatic Analysis. Routledge, London and New York.

Adolphs, S., 2008. Corpus and Context: Investigating Pragmatic Functions in Spoken Discourse. John Benjamins Publishing Company, Amsterdam / Philadelphia.

Al- 'Asqalānī, I., n.d. Fatḥ al-Bārī bi-Sharḥ Saḥị̣ al-'Imām al-Buhāāī 'The Creator's Victory in the Explanation of al-Buhārî's Authentic Collection.' Cairo, Al-Maktaba al-Salafiyya.

AlHedyani, R., 2016. Antonymy in Modern Standard Arabic. PhD thesis, University of Sussex.

Al-Majlasī, M., n.d. Biḥār al-Anwār 'The Seas of Lights'. 'Ihyā' alKutub al-' Islāmiyya, Tehran.

Al-Nawawī, Y., 1987. Sharh Muslim 'Explanation of Saḥị Muslim.' Dār al-Kitāb al- 'Arabī, Beirut.

Al-Sha 'rāwī, M., 1991. Tafsīr al- Sha rāwī 'al- Sha rāwī's Exegesis'.

Dār Ahbār al-Yūm, Cairo.

Al-Ṣi 'īdī', 'A., 1991. Al-Balāgha al- 'Āliya: 'Ilm al-Ma'ān̄̄ 'The Advanced Rhetoric: Semantics'. $2^{\text {nd }}$ ed. Maktabat al-Ādāb, Cairo.

Al-Suyūṭ̣̂, J., 1986. Hashiyat al-Suyūṭ̄ 'alā Sunan al-Nasā'̄i. $2^{\text {nd }}$ ed. Maktabat al-Maṭbū'āt al- 'Islāmiyya, Aleppo.

Al-Zamahsharī, A., 1998. Al-Kashshāf 'The Detector'. $1^{\text {st }}$ ed. Revis.

by 'Ā. A. 'Abd al-Mawjūd and 'A. M. Mu'awwaḍ. Maktabat al'Ubaykān, Riyadh.

Bussmann, H., 1996. Routledge Dictionary of Language and Linguistics. Trans. and edit. by Gregory P. Trauth and Kerstin Kazzazi. Routledge, London and New York. 
Cruse, A., 1976. Three classes of antonym in English. Lingua 38, 281292.

Cruse, A., 1986. Lexical Semantics. Cambridge University Press, Cambridge.

Cruse, A., 2000. Meaning in Language: An Introduction to Semantics and Pragmatics. Oxford University Press, Oxford.

Cruse, A., 2006. A Glossary of Semantics and Pragmatics. Edinburgh University Press, Edinburgh.

Dash, N., 2008. Corpus Linguistics: An introduction. Pearson Longman, Delhi.

Davies, M., 2012. A new approach to oppositions in discourse: the role of syntactic frames in the triggering of noncanonical oppositions. Journal of English Linguistics 40 (1), 41-73.

Davies, M., 2013. Oppositions and Ideology in News Discourse. Bloomsbury, London.

Fellbaum, C., 1995. Co-occurrence and antonymy. International Journal of Lexicography 8 (4), 281-303.

Greimas, A., 1983. Structural Semantics: An Attempt at a Method. Trans. by Daniele McDowell, Ronald Schleifer, and Alan Velie. University of Nebraska Press, Lincoln.

Hassanein, H., 2009. A semiotic analysis of Moses and Pharaoh narrative in the Qur'an. The American Journal of Semiotics 1-2, 25-52.

Hassanein, H., 2013a. The Lexical Semantics of Antonymy in the Qur'an: A linguistic Study. PhD thesis, Benha University.

Hassanein, H., 2013b. A structural-cognitive semiotic analysis of the Qur'anic story Joseph and his Brothers. The Public Journal of Semiotics 5 (2), 47-74.

Hassanein, H., 2017. Translating aspects of lexical-semantic opposition from Qur'anic Arabic into English: a cross-linguistic 
perspective. Perspectives: Studies in Translatology 25 (1), $137-$ 156.

Hassanein, H., 2018. Discourse functions of opposition in Classical Arabic: the case in Hadīth Genre. Lingua 201, 18-44.

Hsu, C., 2015. A syntagmatic analysis of antonym co-occurrences in Chinese: contrastive constructions and co-occurrence sequences. Corpora 10 (1), 47-82.

Hurford, J., Heasley, b., Smith, M., 2007. Semantics: A Coursebook. $2^{\text {nd }}$ ed. Cambridge University Press, Cambridge.

Ibn 'Āshūr, M., 1984. Tafsīr al-Tahrīir wa al-Tanwīr 'The Exegesis of Liberation and Enlightenment'. Al-Dār al-Tūnisiya Li-nashr, Tunisia.

Jones, S., 2002. Antonymy: A Corpus-Based Perspective. Routledge, London and New York.

Jones, S., Murphy, L., 2003. Antonymy in childhood: a corpus-based approach to acquisition. In: Archer, D., Rayson, P., Wislon, A. McEnery, T. (Eds.). UCREL technical paper number 16: Lancaster University Proceedings of the Corpus Linguistics 2003 Conference, p. 372.

Jones, S., Murphy, L., 2005. Using corpora to investigate antonymy acquisition. International Journal of Corpus Linguistics 10 (3), 393-413.

Jones, S., 2006. A lexico-syntactic analysis of antonym co-occurrence in spoken English. Text and Talk 26(2), 191-216.

Jones, S., 2007. 'Opposites' in discourse: A comparison of antonym use across four domains. Journal of Pragmatics 39, 1105-1119.

Jones, S., Paradis, C., Murphy, L., Willners, C., 2007. Googling for opposites: a web-based study of antonym canonicity. Corpora 2 (2), 129-154. 
Jones, S., Murphy, L., Paradis, C., Willners, C., 2012. Antonyms in English: Construals, Constructions and Canonicity. Cambridge University Press, Cambridge.

Justeson, J., Katz, S., 1991. Co-occurrences of antonymous adjectives and their contexts. Computational Linguistics 17(1), 1-19.

Kostić, N., 2011. Antonymous frameworks in Serbian written discourse: phrasal contexts of antonym co-occurrence in text. Poznań Studies in Contemporary Linguistics 47(3), 509-537.

Kostić, N., 2015. Antonymy in language use: from core members to ad hoc couplings. Poznań Studies in Contemporary Linguistics 51 (1), 133-161.

Kostić, N., 2016. On conceptual nature of antonymy: evidence from corpus-based investigations. Journal of Foreign Language Teaching and Applied Linguistics 3 (1), 1-11.

Leech, G., Short, M., 2007. Style in Fiction: A Linguistic Introduction to English Fictional Prose. $2^{\text {nd }}$ ed. Pearson, Harlow.

Lehrer, A., Lehrer, K., 1982. Antonymy. Linguistics and Philosophy 5, 483-501.

Lobanova, A., Kleij, T. van der, Spenader, J., 2010. Defining antonymy: a corpus-based study of opposites by lexico-syntactic patterns. International Journal of Lexicography 23 (1), 19-53.

Lyons, J., 1968. Introduction to Theoretical Linguistics. Cambridge University Press, Cambridge.

Lyons, J., 1977. Semantics. Cambridge University Press, Cambridge.

Lyons, J., 1995. Linguistic Semantics: An Introduction. Cambridge University Press, Cambridge.

Mautner, G., 2009. Corpora and critical discourse analysis. In: Baker, P. (Ed.), Contemporary Corpus Linguistics. Continuum, London and New York, pp. 32-46. 
Mettinger, A., 1994. Aspects of Semantic Opposition in English. Oxford University Press, Oxford.

Muehleisen, V., Isono, M., 2009. Antonymous adjectives in Japanese discourse. Journal of Pragmatics 41 (11), 2185-2203.

Murphy, G., Andrew, J., 1993. The conceptual basis of antonymy and synonymy in adjectives. Journal of Memory and Language 32, 301-319.

Murphy, L., 2003. Semantic Relations and the Lexicon: Antonymy, Synonymy, and Other Paradigms. Cambridge University Press, Cambridge.

Murphy, L., Jones, S., 2008. Antonyms in children's and childdirected speech. First Language, 28 (4), 403-430.

Murphy, L., Paradis, C., Willners, C., Jones, S., 2009. Discourse functions of antonymy: a cross-linguistic investigation of Swedish and English. Journal of Pragmatics 41(11), 2159-2184.

Paradis, C. Willners, C., Jones, S., 2009. Good and bad opposites: using textual and experimental techniques to measure antonym canonicity. The Mental Lexicon 4 (3), 380-429.

Simpson, P., 2004. Stylistics: A Resource Book for Students. Routledge, London and New York.

Stamenov, M. (ed.), 1992. Current Advances in Semantic Theory. John Benjamins Publishing Company, Amsterdam / Philadelphia.

Weijer, J., Paradis, C., Willners, C., Lindgren, M., 2014. Antonym canonicity: temporal and contextual manipulations. Brain Language 128, 1-8. 